Article

\title{
The Effect of Plant Additives on the Stability of Polyphenols in Cloudy and Clarified Juices from Black Chokeberry (Aronia melanocarpa)
}

\author{
Andrzej Sidor ${ }^{1} \mathbb{D}$, Agnieszka Drożdżyńska ${ }^{2}$, Anna Brzozowska $^{1}$, Artur Szwengiel $^{3}{ }^{\mathbb{D}}$ and \\ Anna Gramza-Michałowska 1,*(D) \\ 1 Department of Gastronomy Sciences and Functional Foods, Faculty of Food Science and Nutrition, \\ Poznań University of Life Sciences, Wojska Polskiego 31, 60624 Poznań, Poland; \\ andrzej.sidor@up.poznan.pl (A.S.); anna.brzozowska@up.poznan.pl (A.B.) \\ 2 Department of Biotechnology and Food Microbiology, Faculty of Food Science and Nutrition, \\ Poznań University of Life Sciences, Wojska Polskiego 31, 60624 Poznań, Poland; \\ agnieszka.drozdzynska@up.poznan.pl \\ 3 Institute of Food Technology of Plant Origin, Faculty of Food Science and Nutrition, \\ Poznań University of Life Sciences, Wojska Polskiego 31, 60624 Poznań, Poland; \\ artur.szwengiel@up.poznan.pl \\ * Correspondence: anna.gramza@up.poznan.pl; Tel.: +48-61-848-7327
}

Received: 14 July 2020; Accepted: 25 August 2020; Published: 27 August 2020

\begin{abstract}
Black chokeberry (Aronia melanocarpa) is a fruit with increasing popularity in consumption and processing. Recent research has strengthened the position of chokeberry as a source of phenolic compounds, antioxidants with high pro-health values, therefore it is important to investigate other substances protecting biologically active compounds during juice processing. This study was an attempt to reduce the loss of polyphenol in cloudy and clarified chokeberry juice by adding aqueous cinnamon and clove extracts. The results showed that the clarification of juices did not cause significant changes in the concentration of polyphenols. However, the addition of plant extracts prior to pasteurisation process influenced the content of phenolic compounds in the chokeberry juices. The main change in the composition of the chokeberry juices observed during storage was a result of the degradation process of anthocyanins. The research showed that, despite the common view about the beneficial effects of polyphenols and other compounds exhibiting mutual antioxidative potential, it is very difficult to inhibit the degradation process.
\end{abstract}

Keywords: black chokeberry; Aronia melanocarpa; cinnamon; Cinnamomum; clove; Syzygium aromaticum; juice; polyphenols; anthocyanin

\section{Introduction}

Black chokeberry (Aronia melanocarpa, Rosaceae) is a perennial fruiting shrub that is gaining popularity [1,2]. The plant has various advantages: its fruits have great health-promoting potential, it is relatively easy to cultivate, and it yields large amounts of fruit [3,4]. The properties of chokeberry are mostly related with its high antioxidative activity that results from the presence of polyphenols, including cyanidin-3-O-glycosides (galactoside, arabinoside, xyloside and glucoside), quercetin (galactoside, glucoside, rutinoside, vicianoside and robinobioside), chlorogenic and neochlorogenic acids, and proanthocyanidins [5-12].

The availability of fresh fruits is periodic (from mid-August to late September), and the short shelf-life necessitates their further processing. Chokeberries are processed into juices, dried fruits, jams, syrups, teas, tinctures, jellies, food colourings, dietary supplements, etc. Fruit processing involves 
changes in the content of bioactive compounds resulting from the effect of chemical and physical factors [13]. During processing, fruit components are degraded mostly by increased temperature, oxygen and enzymes, e.g., polyphenol oxidase (PPO) [14]. The results of many studies do not support the fact that the addition of antioxidants from other sources prevents loss of native compounds. In fact, the unpredictable effect of enhancing or suppressing activity in a mixture of different active compounds is often overlooked. Therefore, researchers are conducting investigations to understand the effects and effectiveness of interactions between raw materials, pure compounds and products with antioxidative properties. Furthermore, the addition of plant extracts could increase the biological potential of the obtained drinks. Cinnamon has antitumor, antiinflammatory, antidiabetic, antiobesity, antibacterial, antiviral, cardiovascular protective, cytoprotective, neuroprotective and immunoregulation activity [15]. Cloves pharmaceutical purposes are antimicrobial (antibacterial, antifungal, anticandidal), antiviral, antiinflammatory and anticancer [16,17]. Both spices, cinnamon and cloves contain polyphenolic compounds. Cinnamon contains phenolic acids (caffeic, chlorogenic, ferulic, $p$-coumaric, $p$-hydroxybenzoic, protocatechuic, rosmarinic, syringic), flavonols (rutin, quercetin, quercitrin, kaempferol, isorhamentin), flavone (apigenin), flavanols (catechin, epicatechin), procyanidins, and non-flavonoid phenoglycosides [18-21]. In contrast, cloves contain phenolic acids (gallic, caffeic), flavonols (tamarixetin 3-O- $\beta$-D-glucopyranoside, ombuin 3-O- $\beta$-D-glucopyranoside, quercetin) and ellagitannins (casuarictin, eugeniin, tellimagrandin I and 1,3-di-Ogalloyl-4,6-O-(S) -hexahydroxydiphenoyl- $\beta$-D-glucose [22-24].

In this study, the profile of bioactive compounds in chokeberry juices enriched with cinnamon or clove extracts subjected to processing has been analysed for the first time. Therefore, the aim of the study was to analyse the influence of spices extracts addition, the technological processes (clarifying, pasteurisation) and the storage time on the changes of selected polyphenols content in chokeberry juices.

\section{Materials and Methods}

\subsection{Reagents}

The following HPLC- or LC-MS-grade reagents were used for analyses: acetonitrile, L-ascorbic acid, methanol (Sigma-Aldrich, Poland), acetic acid (Baker, Poland), and formic acid (VWR Int., Poland). The qualitative and quantitative content of polyphenolic compounds was determined with the following standards: 3,4-dihydroxybenzoic acid, 4-hydroxybenzoic acid, chlorogenic acid, caffeic acid, gallic acid, isovanilic acid, kaempferol, luteolin, neochlorogenic acid, orientin (luteolin-8-glucoside), $p$-coumaric acid, procyanidin B2, quercetin, quercetin-3-O-glucoside (Sigma-Aldrich, Poland), (+)-catechin, (-)-epicatechin, quercetin-3-O-galactoside, quercetin-3-O-rutinoside, quercetin-3-O-vicianoside (Extrasynthese, France), cyanidin-3-O-arabinoside, cyanidin-3-O-galactoside, cyanidin-3-O-glucoside (Polyphenols Laboratories AS, Norway) and cyanidin-3-O-xyloside (Toronto Research Chemicals, Canada).

\subsection{Sample Preparation}

The chokeberry fruits (Aronia melanocarpa) were purchased at the Agricultural and Orchard Experimental Farm (Przybroda, Poland). According to the guidelines of the Polish Standard PN-R-75032: 1996 [25], the fruits belonged to the extra quality class. Cinnamon spice plants (KOTÁNYI Polonia, Poland) and cloves (McCormick, Poland) were purchased in a chain store.

On harvesting, the fruits were cleaned, separated and washed. The clean fruits were frozen and stored for 8 weeks. Before pressing juice, the fruits were thawed at about $20^{\circ} \mathrm{C}$ and processed with a blender. Chokeberry puree was pressed in a bladder press at a pressure of 3 bar for 5 min. Obtained juice was diluted with water at a 3:1 ratio and then divided into two parts. Part of the juice was clarified by membrane filtering. The efficiency of the process was visually determined by the absence of suspended high molecular solids such as protein. The other part was left cloudy. Clove and 
cinnamon aqueous extracts were prepared according to the method developed by Gülçin et al. [26]. The spices were ground and added to boiling water at a ratio of 1:20 and boiled for $15 \mathrm{~min}$. The cooled extract was filtered. The clear and cloudy juices were poured into $120 \mathrm{~mL}$ glass jars with galvanised and varnished steel with a gasket closures then cinnamon or clove extract were added in proportion 95:5 v/v. Volume juice/drink in each jar was $100 \mathrm{~mL}$, while the addition of extracts at the level of $5 \%$ was preceded by sensory optimisation using a consumer panel. Juices with ascorbic acid contains ascorbic acid addition to final concentration $300 \mathrm{mg} / \mathrm{L}$ according to nutrition standards [27]. Juices without additives were taken as controls. The juices were closed with lids and pasteurised at $80{ }^{\circ} \mathrm{C}$ for $10 \mathrm{~min}$ [28]. Next, they were cooled with a stream of cold water and stored for 90 days in a dark place at ambient temperature $\left(20 \pm 1^{\circ} \mathrm{C}\right)$. Each juice/drink version was prepared in triplicate.

\subsection{HPLC Analysis of Chokeberry Juices/Drinks Polyphenolic Compounds}

The juices/drinks for chromatographic analysis were diluted with a mixture, which consisted of $150 \mathrm{~mL}$ HPLC grade methanol $\geq 99.9 \%, 345 \mathrm{~mL}$ deionised water, $0.5 \mathrm{~mL}$ HPLC grade acetic acid $\geq 99.7 \%$ and $1 \mathrm{~g}$ ascorbic acid [29]. The diluted juices/drinks were purified by passing through $0.45 \mu \mathrm{m}$ PTFE syringe filters. Next, they were analysed.

An Agilent Technologies 1200 series liquid chromatograph (Agilent Technologies, USA) equipped with an autosampler (G1329B), pump (G1312B) and diode detector (G1315C) with a spectrum range of 190-400 nm was used for the analysis. The signal was recorded for four wavelengths corresponding to the following groups of compounds: polyphenols $(280 \mathrm{~nm})$, phenolic acids $(320 \mathrm{~nm})$, flavonols $(360 \mathrm{~nm})$, anthocyanins $(520 \mathrm{~nm})$. An SB-C18 column $(50 \mathrm{~mm} \times 4.6 \mathrm{~mm}, 1.8 \mu \mathrm{m}$ particle diameter, Agilent Technologies, USA) thermostatted at $25{ }^{\circ} \mathrm{C}$ was used for measurements. The following eluents were used: A-4.5\% formic acid (LC-MS grade 99\%), B-acetonitrile (HPLC grade $\geq 99.9 \%$ ) at a flow rate of $1 \mathrm{~mL} / \mathrm{min}$, gradient: $0 \mathrm{~min} \mathrm{3 \%} \mathrm{B,} 7 \mathrm{~min} \mathrm{9 \%} \mathrm{B,} 13 \mathrm{~min} 12 \% \mathrm{~B}, 20 \mathrm{~min} 14 \% \mathrm{~B}, 21 \mathrm{~min} 80 \% \mathrm{~B}, 26 \mathrm{~min}$ $80 \%$ B, $27 \mathrm{~min} 3 \%$ B, $36 \mathrm{~min} 3 \%$ B. $10 \mu \mathrm{m}$ samples were applied to the column [30,31]. The ChemStation for LC 3D systems program (Agilent Technologies, USA) was used to compare spectra and retention times with standards so as to identify compounds and do quantitative calculations.

\subsection{Analysis of Polyphenolic Compounds of Spice Plants Extracts in the LC-MS System}

The analysis of polyphenolic compounds in spice plant extracts was performed using reverse phase chromatography using mass spectroscopy on a Dionex UltiMate 3000 UHPLC device (Thermo Fisher Scientific, USA) coupled with a Bruker maXis ultra-high-resolution tandem spectrometer (Bruker Daltonik, Germany) using a quadrupole and a time-of-flight analyser. Ionisation was carried out by electrospray in negative ion mode. A Kinetex ${ }^{\mathrm{TM}} 1.7 \mu \mathrm{m}$ C18 100 A, $100 \times 2.1 \mathrm{~mm}$ column (Phenomenex, USA), thermostated at $40{ }^{\circ} \mathrm{C}$, was used for the chromatographic separation. The mobile phase was solvent A-water with $0.1 \%$ formic acid and solvent B-acetonitrile. The flow rate was set at $0.2 \mathrm{~mL} / \mathrm{min}$ with a linear elution gradient of 5 to $95 \%$ of component B over $20 \mathrm{~min}$. The volume of the injected sample was $3 \mu \mathrm{L}$. The following mass spectrometry parameters with the ESI source were used: capillary voltage $4500 \mathrm{~V}$, nitrogen nebulisation at 1.8 bar pressure, drying gas flow $\left(\mathrm{N}_{2}\right) 9 \mathrm{~L} / \mathrm{min}$ at $200{ }^{\circ} \mathrm{C}$. The ion signal was collected in the range of $80-1200 \mathrm{~m} / \mathrm{z}$. The ESI-MS system was calibrated with sodium formate salt, the molecular weight standard was dosed each time at the beginning of the chromatographic separation.

The results were developed using Data Analysis 4.1 (Bruker Daltonik, Germany). Peaks corresponding to the ions of the analysed compounds $[\mathrm{M}-\mathrm{H}]$ were extracted from the chromatogram and then integrated. Compounds were identified by comparing retention times with standards, and based on molecular weight and structural information from a mass spectrometer. Quantitative analysis was carried out based on prepared standard curves. Results are expressed in $\mu \mathrm{g} / \mathrm{mL}$ of extract. 


\subsection{Anthocyanin Degradation Kinetics}

Cyanidin-3-O-galactoside, arabinoside, xyloside and glucoside degradation over time for each treatment was plotted using first-order reaction rate kinetics and the equation:

$$
\ln C_{t}=\ln C_{0}-k t
$$

where $C_{t}$ is the total concentration at time $t, C_{0}$ is the initial concentration at time zero, $k$ is the first-order rate constant and time $t$ is the storage time (degradation reaction time) in days. The anthocyanin half-life in each mixture was calculated using the equation:

$$
t_{1 / 2}=\frac{\ln 2}{k}=\frac{0.693}{k}[d]
$$

\subsection{Statistical Analysis}

The results are expressed as the mean \pm standard deviation. Analysis of one-way variance (ANOVA) was used to study effect of extracts or ascorbic acid solution addition on polyphenols stability after addition to juice, next during clarification, pasteurisation and storage. Differences between samples were assessed by Tukey's HSD post hoc test. Differences were considered statistically significant when $p \leq 0.05$. Software used for ANOVA test was Statistica 13 (StatSoft, Poland). Reaction rates for anthocyanin degradation were obtained from linear regression conducted using Microsoft Excel 2016.

\section{Results and Discussion}

\subsection{Profile of Polyphenolic Compounds in Juices/Drinks}

Chokeberry juices are rich in polyphenols. The main polyphenols of chokeberry fruits and products are: phenolic acids (chlorogenic and neochlorogenic), flavonols (quercetin-3-O-glucoside, galactoside, rutinoside, vicianoside and robinobioside), anthocyanins (cyanidin-3-O-galactoside, arabinoside, glucoside and xyloside) and proanthocyanidins [2]. Determination of the polyphenol content in the aqueous cinnamon extract showed the presence of: 3,4-dihydroxybenzoic acid $(6.16 \pm 0.37 \mu \mathrm{g} / \mathrm{mL})$, chlorogenic acid $(1.16 \pm 0.00 \mu \mathrm{g} / \mathrm{mL}), p$-coumaric acid $(0.07 \pm 0.00 \mu \mathrm{g} / \mathrm{mL})$, catechin $(5.10 \pm 0.11 \mu \mathrm{g} / \mathrm{mL})$ and procyanidin B2 $(2.37 \pm 0.21 \mu \mathrm{g} / \mathrm{mL})$. The aqueous extract of cloves had more diverse profile of polyphenols: 3,4-dihydroxybenzoic acid $(0.40 \pm 0.04 \mu \mathrm{g} / \mathrm{mL})$, 4-hydroxybenzoic acid $(0.34 \pm 0.02 \mu \mathrm{g} / \mathrm{mL})$, caffeic acid $(1.00 \pm 0.03 \mu \mathrm{g} / \mathrm{mL})$, chlorogenic acid $(48.41 \pm 3.00 \mu \mathrm{g} / \mathrm{mL})$, gallic acid $(18.7 \pm 0.81 \mu \mathrm{g} / \mathrm{mL})$, isovanilic acid $(0.31 \pm 0.01 \mu \mathrm{g} / \mathrm{mL}), p$-coumaric acid $(0.32 \pm 0.02 \mu \mathrm{g} / \mathrm{mL})$, kaempferol $(0.31 \pm 0.01 \mu \mathrm{g} / \mathrm{mL})$, luteolin $(0.12 \pm 0.00 \mu \mathrm{g} / \mathrm{mL})$, orientin $(0.22 \pm 0.02 \mu \mathrm{g} / \mathrm{mL})$, quercetin $(0.57 \pm 0.01 \mu \mathrm{g} / \mathrm{mL})$, quercetin 3-D-galactoside $(0.45 \pm 0.03 \mu \mathrm{g} / \mathrm{mL})$.

The analysis of the composition of the juices/drinks revealed the presence of basic chokeberry polyphenolic compounds. The content of neochlorogenic and chlorogenic acids in the unpasteurised juices/drinks amounted to 30.03-34.77 mg/100 mL and 27.28-32.13 mg/100 mL, respectively (Table 1). Kardum et al. [32] found similar content of phenolic acids in chokeberry juices: $28 \mathrm{mg} / 100 \mathrm{~g}$ (neochlorogenic acid) and $32 \mathrm{mg} / 100 \mathrm{~g}$ (chlorogenic acid). Mayer-Miebach et al. [33] found 21-29 mg/100 mL (neochlorogenic acid) and 20-30 mg/100 g (chlorogenic acid) in chokeberry juice. There were small amounts of flavanols in the unpasteurised juices. The juices contained very little catechin and (-)-epicatechin, regardless of the additive used, in relation to the other compounds found in the tested juices / drinks. It is noteworthy that the content of (-)-epicatechin was more than twice as high as the content of $(+)$-catechin (Table 1$)$. The content of $(+)$-catechin in chokeberry fruit and products is so low that this compound is usually omitted in analyses [34-36]. It should be noted that their evaluation is advisable, because technological processes can affect the decomposition of proanthocyanidins, also known as condensed tannins, the building blocks of which include catechin and epicatechin [37]. 
Table 1. Phenolic acids and flavanols content before and after juice/drink pasteurisation.

\begin{tabular}{|c|c|c|c|}
\hline & \multicolumn{3}{|c|}{ Juice/Drink } \\
\hline & Additive & Unpasteurised & Pasteurised \\
\hline \multicolumn{4}{|c|}{$(+)$-catechin $[\mathrm{mg} / 100 \mathrm{~mL}]$} \\
\hline \multirow{4}{*}{ 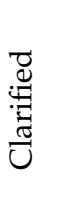 } & No additives & $1.57 \pm 0.00^{\mathrm{A}, \mathrm{a}, \mathrm{b}}$ & $1.51 \pm 0.09 \mathrm{~A}, \mathrm{~b}, \mathrm{c}$ \\
\hline & Ascorbic acid & $1.70 \pm 0.02^{\mathrm{A}, \mathrm{a}, \mathrm{b}}$ & $1.60 \pm 0.03^{\mathrm{B}, \mathrm{a}, \mathrm{b}}$ \\
\hline & Cinnamon extract & $1.57 \pm 0.15^{\mathrm{A}, \mathrm{a}, \mathrm{b}}$ & $1.39 \pm 0.01^{\mathrm{A}, \mathrm{c}}$ \\
\hline & Clove extract & $1.81 \pm 0.02^{\mathrm{A}, \mathrm{a}}$ & $1.73 \pm 0.04^{\mathrm{A}, \mathrm{a}}$ \\
\hline \multirow{4}{*}{$\frac{\overrightarrow{0}}{\frac{0}{0}}$} & No additives & $1.58 \pm 0.02^{\mathrm{A}, \mathrm{a}, \mathrm{b}}$ & $1.52 \pm 0.06^{\mathrm{A}, \mathrm{b}, \mathrm{c}}$ \\
\hline & Ascorbic acid & $1.66 \pm 0.01^{\mathrm{A}, \mathrm{a}, \mathrm{b}}$ & $1.75 \pm 0.09 \mathrm{~A}, \mathrm{a}$ \\
\hline & Cinnamon extract & $1.45 \pm 0.04^{\mathrm{A}, \mathrm{b}}$ & $1.48 \pm 0.02^{\mathrm{A}, \mathrm{b}, \mathrm{c}}$ \\
\hline & Clove extract & $1.70 \pm 0.12^{\mathrm{A}, \mathrm{a}, \mathrm{b}}$ & $1.77 \pm 0.11^{\mathrm{A}, \mathrm{a}}$ \\
\hline \multicolumn{4}{|c|}{ (-)-epicatechin [mg/100 mL] } \\
\hline \multirow{4}{*}{ 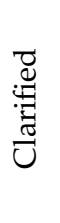 } & No additives & $4.42 \pm 0.02 \mathrm{~A}, \mathrm{~b}$ & $4.53 \pm 0.07^{\mathrm{A}, \mathrm{c}}$ \\
\hline & Ascorbic acid & $4.50 \pm 0.08^{\mathrm{A}, \mathrm{b}}$ & $4.53 \pm 0.06^{\mathrm{A}, \mathrm{c}}$ \\
\hline & Cinnamon extract & $4.63 \pm 0.11^{\mathrm{A}, \mathrm{a}, \mathrm{b}}$ & $4.82 \pm 0.04^{\mathrm{A}, \mathrm{a}}$ \\
\hline & Clove extract & $4.74 \pm 0.07^{\mathrm{A}, \mathrm{a}, \mathrm{b}}$ & $4.79 \pm 0.03^{\mathrm{A}, \mathrm{a}, \mathrm{b}}$ \\
\hline \multirow{4}{*}{$\begin{array}{l}\frac{\overrightarrow{0}}{\overrightarrow{0}} \\
\frac{0}{U}\end{array}$} & No additives & $4.65 \pm 0.02^{\mathrm{A}, \mathrm{a}, \mathrm{b}}$ & $4.66 \pm 0.14^{\mathrm{A}, \mathrm{a}, \mathrm{b}, \mathrm{c}}$ \\
\hline & Ascorbic acid & $4.44 \pm 0.02^{\mathrm{A}, \mathrm{b}}$ & $4.60 \pm 0.09^{\mathrm{A}, \mathrm{b}, \mathrm{c}}$ \\
\hline & Cinnamon extract & $4.62 \pm 0.04^{\mathrm{A}, \mathrm{a}, \mathrm{b}}$ & $4.82 \pm 0.05^{\mathrm{A}, \mathrm{a}}$ \\
\hline & Clove extract & $4.94 \pm 0.18^{\mathrm{A}, \mathrm{a}}$ & $4.86 \pm 0.02^{\mathrm{A}, \mathrm{a}}$ \\
\hline \multicolumn{4}{|c|}{ neochlorogenic acid [mg/100 mL] } \\
\hline \multirow{4}{*}{ 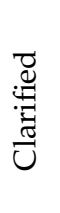 } & No additives & $33.21 \pm 0.51^{\mathrm{A}, \mathrm{a}, \mathrm{b}}$ & $34.05 \pm 0.56^{\mathrm{A}, \mathrm{a}}$ \\
\hline & Ascorbic acid & $34.77 \pm 0.89 \mathrm{~A}, \mathrm{a}$ & $33.86 \pm 0.33^{\mathrm{A}, \mathrm{a}, \mathrm{b}}$ \\
\hline & Cinnamon extract & $31.59 \pm 0.33^{\mathrm{A}, \mathrm{b}, \mathrm{c}}$ & $31.76 \pm 0.68^{\mathrm{A}, \mathrm{b}, \mathrm{c}}$ \\
\hline & Clove extract & $32.91 \pm 0.10^{\mathrm{A}, \mathrm{a}, \mathrm{b}}$ & $32.42 \pm 0.63^{\mathrm{A}, \mathrm{a}, \mathrm{b}, \mathrm{c}}$ \\
\hline \multirow{4}{*}{$\frac{\overrightarrow{0}}{\frac{0}{2}}$} & No additives & $34.70 \pm 1.21^{\mathrm{A}, \mathrm{a}}$ & $34.19 \pm 0.64 \mathrm{~A}, \mathrm{a}$ \\
\hline & Ascorbic acid & $32.80 \pm 0.07^{\mathrm{A}, \mathrm{a}, \mathrm{b}}$ & $31.22 \pm 1.19 \mathrm{~A}, \mathrm{c}$ \\
\hline & Cinnamon extract & $31.82 \pm 0.37^{\mathrm{A}, \mathrm{b}, \mathrm{c}}$ & $31.87 \pm 0.46^{\mathrm{A}, \mathrm{b}, \mathrm{c}}$ \\
\hline & Clove extract & $30.03 \pm 0.72 \mathrm{~A}, \mathrm{c}$ & $30.81 \pm 1.06^{\mathrm{A}, \mathrm{c}}$ \\
\hline \multicolumn{4}{|c|}{ chlorogenic acid [mg/100 mL] } \\
\hline \multirow{4}{*}{ 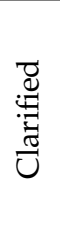 } & No additives & $30.30 \pm 0.04^{\mathrm{A}, \mathrm{a}, \mathrm{b}, \mathrm{c}}$ & $30.97 \pm 0.35^{\mathrm{A}, \mathrm{a}}$ \\
\hline & Ascorbic acid & $32.13 \pm 0.51 \mathrm{~A}, \mathrm{a}$ & $30.82 \pm 0.34^{\mathrm{B}, \mathrm{a}}$ \\
\hline & Cinnamon extract & $28.94 \pm 0.32 \mathrm{~A}, \mathrm{c}, \mathrm{d}$ & $28.98 \pm 0.27^{\mathrm{A}, \mathrm{b}}$ \\
\hline & Clove extract & $30.23 \pm 0.05^{\mathrm{A}, \mathrm{b}, \mathrm{c}}$ & $30.08 \pm 0.46^{\mathrm{A}, \mathrm{a}, \mathrm{b}}$ \\
\hline \multirow{4}{*}{$\frac{\overrightarrow{0}}{\frac{0}{2}}$} & No additives & $31.98 \pm 1.14^{\mathrm{A}, \mathrm{a}, \mathrm{b}}$ & $31.15 \pm 0.64^{\mathrm{A}, \mathrm{a}}$ \\
\hline & Ascorbic acid & $29.39 \pm 0.11^{\mathrm{A}, \mathrm{c}}$ & $28.93 \pm 0.35^{\mathrm{A}, \mathrm{b}}$ \\
\hline & Cinnamon extract & $29.22 \pm 0.06^{\mathrm{A}, \mathrm{c}}$ & $29.25 \pm 0.32^{\mathrm{A}, \mathrm{b}}$ \\
\hline & Clove extract & $27.28 \pm 0.22{ }^{\mathrm{A}, \mathrm{d}}$ & $27.28 \pm 0.54^{\mathrm{A}, \mathrm{c}}$ \\
\hline
\end{tabular}

a, b, c, d-means in a column followed by the same small letter are not significantly different $(p>0.05)$; A, B-means in a row followed by the same capital letter are not significantly different $(p>0.05)$; values are means of three determinations $\pm S D$. 
The extracts of cinnamon, clove and ascorbic acid were also added to juices and drinks, and their effect on the content of phenolic compounds in chokeberry juice was investigated. There was similar content of flavonols both in the juices with and without additives-it ranged from about 2.5 to $4 \mathrm{mg} / 100 \mathrm{~mL}$ (Table 2). The relatively low concentration of individual quercetin glycosides (a few milligrams) is typical of chokeberry juices [12,32].

Table 2. Flavonol content before and after juice/drink pasteurisation.

\begin{tabular}{|c|c|c|c|}
\hline & \multirow[b]{2}{*}{ Additive } & \multicolumn{2}{|c|}{ Juice/Drink } \\
\hline & & Unpasteurised & Pasteurised \\
\hline \multicolumn{4}{|c|}{ quercetin-3-O-vicianoside $[\mathrm{mg} / 100 \mathrm{~mL}]$} \\
\hline \multirow{4}{*}{ 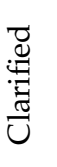 } & No additives & $4.00 \pm 0.07^{\mathrm{B}, \mathrm{a}}$ & $4.86 \pm 0.06^{\mathrm{A}, \mathrm{a}}$ \\
\hline & Ascorbic acid & $4.07 \pm 0.10^{\mathrm{A}, \mathrm{a}}$ & $3.90 \pm 0.05^{\mathrm{A}, \mathrm{b}, \mathrm{c}}$ \\
\hline & Cinnamon extract & $3.68 \pm 0.02^{\mathrm{B}, \mathrm{b}}$ & $3.76 \pm 0.02^{\mathrm{A}, \mathrm{b}, \mathrm{c}}$ \\
\hline & Clove extract & $3.89 \pm 0.00^{\mathrm{A}, \mathrm{a}}$ & $3.79 \pm 0.02^{\mathrm{B}, \mathrm{b}, \mathrm{c}}$ \\
\hline \multirow{4}{*}{$\begin{array}{l}\frac{2}{0} \\
\frac{0}{0} \\
ن\end{array}$} & No additives & $3.90 \pm 0.07^{\mathrm{B}, \mathrm{a}}$ & $4.81 \pm 0.12^{\mathrm{A}, \mathrm{a}}$ \\
\hline & Ascorbic acid & $3.86 \pm 0.03^{\mathrm{A}, \mathrm{a}, \mathrm{b}}$ & $3.82 \pm 0.11^{\mathrm{A}, \mathrm{b}, \mathrm{c}}$ \\
\hline & Cinnamon extract & $3.91 \pm 0.02 \mathrm{~A}, \mathrm{a}$ & $3.99 \pm 0.09 \mathrm{~A}, \mathrm{~b}$ \\
\hline & Clove extract & $3.65 \pm 0.01^{\mathrm{A}, \mathrm{b}}$ & $3.68 \pm 0.21^{\mathrm{A}, \mathrm{c}}$ \\
\hline \multicolumn{4}{|c|}{ quercetin-3-O-galactoside $[\mathrm{mg} / 100 \mathrm{~mL}]$} \\
\hline \multirow{4}{*}{ 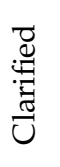 } & No additives & $3.98 \pm 0.05^{\mathrm{B}, \mathrm{a}, \mathrm{b}}$ & $4.28 \pm 0.08^{\mathrm{A}, \mathrm{a}}$ \\
\hline & Ascorbic acid & $4.30 \pm 0.02^{\mathrm{A}, \mathrm{a}}$ & $3.96 \pm 0.06^{\mathrm{B}, \mathrm{b}}$ \\
\hline & Cinnamon extract & $3.60 \pm 0.01^{\mathrm{B}, \mathrm{b}}$ & $3.71 \pm 0.03^{\mathrm{A}, \mathrm{b}, \mathrm{c}}$ \\
\hline & Clove extract & $3.87 \pm 0.01^{\mathrm{A}, \mathrm{a}, \mathrm{b}}$ & $3.76 \pm 0.01^{\mathrm{B}, \mathrm{b}, \mathrm{c}}$ \\
\hline \multirow{4}{*}{$\begin{array}{l}\frac{\overrightarrow{0}}{\frac{0}{3}} \\
\frac{0}{U}\end{array}$} & No additives & $4.00 \pm 0.22 \mathrm{~A}, \mathrm{a}, \mathrm{b}$ & $4.27 \pm 0.12^{\mathrm{A}, \mathrm{a}}$ \\
\hline & Ascorbic acid & $3.99 \pm 0.21^{\mathrm{A}, \mathrm{a}, \mathrm{b}}$ & $3.81 \pm 0.12^{\mathrm{A}, \mathrm{b}, \mathrm{c}}$ \\
\hline & Cinnamon extract & $3.77 \pm 0.04 \mathrm{~A}, \mathrm{~b}$ & $3.87 \pm 0.07^{\mathrm{A}, \mathrm{b}, \mathrm{c}}$ \\
\hline & Clove extract & $3.59 \pm 0.03^{\mathrm{A}, \mathrm{b}}$ & $3.59 \pm 0.21^{\mathrm{A}, \mathrm{c}}$ \\
\hline \multicolumn{4}{|c|}{ quercetin-3-O-rutinoside $[\mathrm{mg} / 100 \mathrm{~mL}]$} \\
\hline \multirow{4}{*}{ 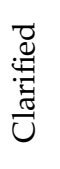 } & No additives & $3.76 \pm 0.09^{\mathrm{B}, \mathrm{a}, \mathrm{b}}$ & $4.11 \pm 0.04^{\mathrm{A}, \mathrm{a}}$ \\
\hline & Ascorbic acid & $4.10 \pm 0.10^{\mathrm{A}, \mathrm{a}}$ & $3.71 \pm 0.06^{\mathrm{B}, \mathrm{b}}$ \\
\hline & Cinnamon extract & $3.44 \pm 0.04^{\mathrm{A}, \mathrm{b}}$ & $3.54 \pm 0.04^{\mathrm{A}, \mathrm{c}}$ \\
\hline & Clove extract & $3.93 \pm 0.02 \mathrm{~A}, \mathrm{a}, \mathrm{b}$ & $3.89 \pm 0.04^{\mathrm{A}, \mathrm{a}, \mathrm{b}, \mathrm{c}}$ \\
\hline \multirow{4}{*}{$\frac{\overrightarrow{0}}{\frac{0}{2}}$} & No additives & $3.90 \pm 0.34^{\mathrm{A}, \mathrm{a}, \mathrm{b}}$ & $4.12 \pm 0.10^{\mathrm{A}, \mathrm{a}}$ \\
\hline & Ascorbic acid & $3.90 \pm 0.24^{\mathrm{A}, \mathrm{a}, \mathrm{b}}$ & $3.71 \pm 0.13^{\mathrm{A}, \mathrm{b}, \mathrm{c}}$ \\
\hline & Cinnamon extract & $3.73 \pm 0.01^{\mathrm{A}, \mathrm{a}, \mathrm{b}}$ & $3.77 \pm 0.09 \mathrm{~A}, \mathrm{a}, \mathrm{b}, \mathrm{c}$ \\
\hline & Clove extract & $3.79 \pm 0.03^{\mathrm{A}, \mathrm{a}, \mathrm{b}}$ & $4.03 \pm 0.31 \mathrm{~A}, \mathrm{a}, \mathrm{b}$ \\
\hline \multicolumn{4}{|c|}{ quercetin 3-O-glucoside [mg/100 mL] } \\
\hline \multirow{4}{*}{ 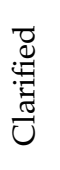 } & No additives & $2.51 \pm 0.05^{\mathrm{A}, \mathrm{a}, \mathrm{b}, \mathrm{c}}$ & $2.52 \pm 0.05^{\mathrm{A}, \mathrm{b}, \mathrm{c}}$ \\
\hline & Ascorbic acid & $2.76 \pm 0.05^{\mathrm{A}, \mathrm{a}, \mathrm{b}}$ & $2.53 \pm 0.03^{\mathrm{B}, \mathrm{b}, \mathrm{c}}$ \\
\hline & Cinnamon extract & $2.28 \pm 0.03^{\mathrm{B}, \mathrm{c}}$ & $2.37 \pm 0.01^{\mathrm{A}, \mathrm{c}}$ \\
\hline & Clove extract & $2.80 \pm 0.01 \mathrm{~A}, \mathrm{a}$ & $2.74 \pm 0.01^{\mathrm{B}, \mathrm{a}}$ \\
\hline \multirow{4}{*}{$\frac{2}{\frac{D}{0}}$} & No additives & $2.62 \pm 0.16^{\mathrm{A}, \mathrm{a}, \mathrm{b}, \mathrm{c}}$ & $2.54 \pm 0.06^{\mathrm{A}, \mathrm{b}, \mathrm{c}}$ \\
\hline & Ascorbic acid & $2.61 \pm 0.18^{\mathrm{A}, \mathrm{a}, \mathrm{b}, \mathrm{c}}$ & $2.48 \pm 0.08 \mathrm{~A}, \mathrm{~b}, \mathrm{c}$ \\
\hline & Cinnamon extract & $2.41 \pm 0.03^{\mathrm{A}, \mathrm{b}, \mathrm{c}}$ & $2.47 \pm 0.04^{\mathrm{A}, \mathrm{b}, \mathrm{c}}$ \\
\hline & Clove extract & $2.62 \pm 0.08^{\mathrm{A}, \mathrm{a}, \mathrm{b}}$ & $2.62 \pm 0.14^{\mathrm{A}, \mathrm{a}, \mathrm{b}}$ \\
\hline
\end{tabular}

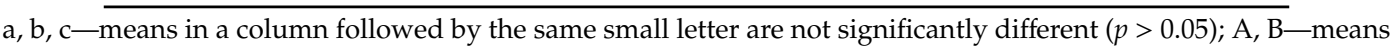
in a row followed by the same capital letter are not significantly different $(p>0.05)$; values are means of three determinations \pm SD.

The analysis of the clarification process on the phenolic composition of the juices/drinks was conducted. The clarified and cloudy chokeberry juices/drinks without additives had the following content of anthocyanins before pasteurisation: cyanidin-3-O-galactoside- $74.88-77.34 \mathrm{mg} / 100 \mathrm{~mL}$ and cyanidin-3-O-arabinoside-58.52-60.28 $\mathrm{mg} / 100 \mathrm{~mL}-$ the highest concentrations; cyanidin-3-O-xyloside-9.19-9.21 mg/100 mL and cyanidin-3-O-glucoside-4.16-5.12 mg/100 mL-the 
lowest concentrations (Table 3). The content of individual cyanidins in chokeberry juices may vary significantly. The ratio of individual cyanidins in juice is not constant, either [33,38,39]. Based on the latest research, the composition of anthocyanins and other polyphenols in chokeberry fruit and products is much more diverse $[40,41]$.

Table 3. Cyanidin content before and after juice/drink pasteurisation.

\begin{tabular}{|c|c|c|c|}
\hline & \multirow[b]{2}{*}{ Additive } & \multicolumn{2}{|c|}{ Juice/Drink } \\
\hline & & Unpasteurised & Pasteurised \\
\hline \multirow{5}{*}{ 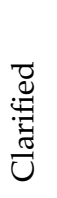 } & cyanidin-3- & lactoside $\left[\mathrm{mg} / 100_{1}\right.$ & \\
\hline & No additives & $74.88 \pm 0.63^{\mathrm{A}, \mathrm{a}}$ & $73.93 \pm 2.32 \mathrm{~A}, \mathrm{a}, \mathrm{b}$ \\
\hline & Ascorbic acid & $74.87 \pm 3.05^{\mathrm{A}, \mathrm{a}}$ & $74.33 \pm 1.45^{\mathrm{A}, \mathrm{a}, \mathrm{b}}$ \\
\hline & Cinnamon extract & $68.65 \pm 2.61^{\mathrm{A}, \mathrm{a}, \mathrm{b}}$ & $68.44 \pm 1.12^{\mathrm{A}, \mathrm{b}, \mathrm{c}}$ \\
\hline & Clove extract & $70.47 \pm 1.41^{\mathrm{A}, \mathrm{a}, \mathrm{b}}$ & $69.15 \pm 1.31^{\mathrm{A}, \mathrm{b}, \mathrm{c}}$ \\
\hline \multirow{4}{*}{$\begin{array}{l}\frac{\overrightarrow{0}}{\frac{0}{0}} \\
\frac{0}{U}\end{array}$} & No additives & $77.34 \pm 3.94^{\mathrm{A}, \mathrm{a}}$ & $76.91 \pm 1.92 \mathrm{~A}, \mathrm{a}$ \\
\hline & Ascorbic acid & $72.23 \pm 0.86^{\mathrm{A}, \mathrm{a}, \mathrm{b}}$ & $69.58 \pm 0.46^{\mathrm{B}, \mathrm{b}, \mathrm{c}}$ \\
\hline & Cinnamon extract & $64.69 \pm 0.96^{\mathrm{A}, \mathrm{b}}$ & $64.10 \pm 2.30^{\mathrm{A}, \mathrm{c}}$ \\
\hline & Clove extract & $70.33 \pm 2.12^{\mathrm{A}, \mathrm{a}, \mathrm{b}}$ & $66.07 \pm 4.08^{\mathrm{A}, \mathrm{c}}$ \\
\hline \multicolumn{4}{|c|}{ cyanidin-3-O-glucoside $[\mathrm{mg} / 100 \mathrm{~mL}]$} \\
\hline \multirow{4}{*}{ 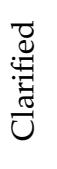 } & No additives & $5.03 \pm 0.00 \mathrm{~A}, \mathrm{a}$ & $4.91 \pm 0.22 \mathrm{~A}, \mathrm{a}, \mathrm{b}$ \\
\hline & Ascorbic acid & $5.03 \pm 0.23^{\mathrm{A}, \mathrm{a}}$ & $4.92 \pm 0.12^{\mathrm{A}, \mathrm{a}, \mathrm{b}}$ \\
\hline & Cinnamon extract & $4.56 \pm 0.21^{\mathrm{A}, \mathrm{a}, \mathrm{b}}$ & $4.48 \pm 0.06^{\mathrm{A}, \mathrm{b}, \mathrm{c}}$ \\
\hline & Clove extract & $4.69 \pm 0.01^{\mathrm{A}, \mathrm{a}, \mathrm{b}}$ & $4.59 \pm 0.10^{\mathrm{A}, \mathrm{b}, \mathrm{c}}$ \\
\hline \multirow{4}{*}{$\begin{array}{l}\frac{2}{0} \\
\frac{0}{2} \\
\frac{0}{U}\end{array}$} & No additives & $5.12 \pm 0.29 \mathrm{~A}, \mathrm{a}$ & $5.16 \pm 0.16^{\mathrm{A}, \mathrm{a}}$ \\
\hline & Ascorbic acid & $4.79 \pm 0.03^{\mathrm{A}, \mathrm{a}, \mathrm{b}}$ & $4.47 \pm 0.01^{\mathrm{B}, \mathrm{b}, \mathrm{c}}$ \\
\hline & Cinnamon extract & $4.16 \pm 0.09 \mathrm{~A}, \mathrm{~b}$ & $4.35 \pm 0.11^{\mathrm{A}, \mathrm{c}}$ \\
\hline & Clove extract & $4.64 \pm 0.13^{\mathrm{A}, \mathrm{a}, \mathrm{b}}$ & $4.23 \pm 0.33^{\mathrm{A}, \mathrm{c}}$ \\
\hline \multicolumn{4}{|c|}{ cyanidin-3-O-arabinoside $[\mathrm{mg} / 100 \mathrm{~mL}]$} \\
\hline \multirow{4}{*}{ 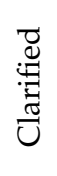 } & No additives & $58.52 \pm 0.76^{\mathrm{A}, \mathrm{a}}$ & $54.40 \pm 2.66^{\mathrm{A}, \mathrm{a}, \mathrm{b}}$ \\
\hline & Ascorbic acid & $58.40 \pm 2.49^{\mathrm{A}, \mathrm{a}}$ & $58.04 \pm 1.49^{\mathrm{A}, \mathrm{a}}$ \\
\hline & Cinnamon extract & $53.07 \pm 2.27^{\mathrm{A}, \mathrm{a}, \mathrm{b}}$ & $52.54 \pm 0.83^{\mathrm{A}, \mathrm{a}, \mathrm{b}}$ \\
\hline & Clove extract & $54.97 \pm 0.84^{\mathrm{A}, \mathrm{a}, \mathrm{b}}$ & $53.31 \pm 1.42^{\mathrm{A}, \mathrm{a}, \mathrm{b}}$ \\
\hline \multirow{4}{*}{$\begin{array}{l}\frac{\lambda}{0} \\
\frac{0}{2} \\
\frac{0}{U}\end{array}$} & No additives & $60.28 \pm 3.70^{\mathrm{A}, \mathrm{a}}$ & $57.63 \pm 1.97^{\mathrm{A}, \mathrm{a}}$ \\
\hline & Ascorbic acid & $56.06 \pm 1.39 \mathrm{~A}, \mathrm{a}, \mathrm{b}$ & $52.22 \pm 2.16^{\mathrm{A}, \mathrm{a}, \mathrm{b}}$ \\
\hline & Cinnamon extract & $48.25 \pm 1.57^{\mathrm{A}, \mathrm{b}}$ & $51.23 \pm 2.76^{\mathrm{A}, \mathrm{b}}$ \\
\hline & Clove extract & $55.03 \pm 3.05^{\mathrm{A}, \mathrm{a}, \mathrm{b}}$ & $49.83 \pm 3.46^{\mathrm{A}, \mathrm{b}}$ \\
\hline \multicolumn{4}{|c|}{ cyanidin-3-O-xyloside $[\mathrm{mg} / 100 \mathrm{~mL}]$} \\
\hline \multirow{4}{*}{ 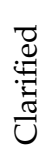 } & No additives & $9.21 \pm 0.21 \mathrm{~A}, \mathrm{a}, \mathrm{b}$ & $9.25 \pm 0.42^{\mathrm{A}, \mathrm{a}, \mathrm{b}}$ \\
\hline & Ascorbic acid & $9.43 \pm 0.53^{\mathrm{A}, \mathrm{a}}$ & $9.22 \pm 0.32^{\mathrm{A}, \mathrm{a}, \mathrm{b}}$ \\
\hline & Cinnamon extract & $8.29 \pm 0.31^{\mathrm{A}, \mathrm{b}, \mathrm{c}}$ & $8.29 \pm 0.15^{\mathrm{A}, \mathrm{b}}$ \\
\hline & Clove extract & $9.00 \pm 0.05^{\mathrm{A}, \mathrm{a}, \mathrm{b}}$ & $8.59 \pm 0.26^{\mathrm{A}, \mathrm{b}}$ \\
\hline \multirow{4}{*}{$\begin{array}{l}\frac{\lambda}{0} \\
\frac{0}{0} \\
ن\end{array}$} & No additives & $9.19 \pm 0.11^{\mathrm{A}, \mathrm{a}, \mathrm{b}}$ & $9.82 \pm 0.37^{\mathrm{A}, \mathrm{a}}$ \\
\hline & Ascorbic acid & $8.60 \pm 0.10^{\mathrm{A}, \mathrm{a}, \mathrm{b}, \mathrm{c}}$ & $8.97 \pm 0.27^{\mathrm{A}, \mathrm{a}, \mathrm{b}}$ \\
\hline & Cinnamon extract & $7.81 \pm 0.25^{\mathrm{A}, \mathrm{c}}$ & $8.08 \pm 0.25^{\mathrm{A}, \mathrm{b}}$ \\
\hline & Clove extract & $8.65 \pm 0.35^{\mathrm{A}, \mathrm{a}, \mathrm{b}, \mathrm{c}}$ & $8.35 \pm 0.91 \mathrm{~A}, \mathrm{~b}$ \\
\hline
\end{tabular}

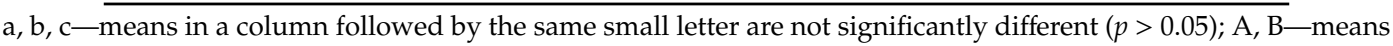
in a row followed by the same capital letter are not significantly different $(p>0.05)$; values are means of three determinations $\pm \mathrm{SD}$.

The clarification of the juices by filtration did not cause significant losses of polyphenols. Similarly, White et al. [42] did not observe losses of anthocyanins, flavonols and proanthocyanidins in cranberry juice clarified by sedimentation. At the next stage, extracts of selected plants were added to the juices/drinks. The analysis showed that the addition of spice plant extracts to the unpasteurised juices caused a slight decrease in the anthocyanin content. These changes were minimal. They were 
statistically significant only when cinnamon extract was added. The addition of the extracts to the cloudy juices/drinks caused a decrease in the content of phenolic acids.

\subsection{The Effect of the Pasteurisation Process on the Content of Polyphenolic Compounds in Juices/Drinks}

The influence of pasteurisation on the content of polyphenolic compounds in the juices/drinks was also analysed. The process $\left(80^{\circ} \mathrm{C}, 10 \mathrm{~min}\right)$ usually did not change the composition of polyphenols. There were few differences in the concentration of cyanidins, flavanols and phenolic acids as well as frequent changes in the concentration of flavonols (Tables 1-3). The pasteurisation of the clarified juices without the additives caused the content of quercetin-3-O-vicianoside, galactoside and rutinoside to increase. The pasteurisation of the cloudy juices without the additives reduced the concentration of quercetin-3-O-vicianoside. The pasteurised clarified juice with ascorbic acid contained less quercetin-3-O-galactoside, rutinoside and glucoside than the corresponding juice/drink before pasteurisation. Wilkes et al. [43] observed that during the pasteurisation of chokeberry juice the content of cyanidins and neochlorogenic acid decreased. There was also a small but statistically significant loss of flavonols. Simultaneously, as the concentration of quercetin glycosides decreased, the concentration of quercetin in the form of aglycon increased.

The thermal treatment $\left(85^{\circ} \mathrm{C}, 30 \mathrm{~min}\right)$ of pomegranate juice during aseptic filling did not cause a decrease in the content of some anthocyanins, including cyanidin-3-O-glucoside, which can also be found in chokeberry juice. However, the total anthocyanin content decreased by $3.92 \%$ during heating. The changes were statistically significant. The heating of juice at $95{ }^{\circ} \mathrm{C}$ for $45 \mathrm{~s}$ caused a decrease in the concentration of all anthocyanins. The total anthocyanin concentration decreased from 269.88 to $230.03 \mathrm{mg} / \mathrm{L}$ [44]. Based on the publications cited above, the degradation of anthocyanins during pasteurisation is influenced by raw material, temperature and heating time. The anthocyanin content is sometimes higher in the differential method from HPLC when the results are expressed as equivalents of the same compound. If anthocyanin standards are used in HPLC, the sum of anthocyanins is rather higher than the result obtained by the differential method [45]. In six out of seven juices/drinks using the differential method performed in cuvettes or plates, the content of anthocyanins was lower than the results of measurements from two HPLC systems [46]. Another factor that may affect the anthocyanin transformation during pasteurisation is the method of juice production, including the preparation of raw material, e.g., whole fruit, crushed fruit [41,42]. The influence of the additives (cinnamon and clove extracts) on the polyphenol content was only noticeable in the clarified juices/drinks. It affected only flavonols. The pasteurisation of the clarified juice/drink with the clove extract additive caused a decrease in the content of quercetin-3-O-vicianoside and quercetin-3-O-galactoside. It also caused an increase in the content of quercetin-3-O-glucoside (Table 2). The addition of cinnamon extract during the pasteurisation of the clarified juice/drink caused an increase in the content of quercetin-3-O-glycosides (vicianoside, galactoside, glucoside). The pasteurisation $\left(85^{\circ} \mathrm{C}, 6 \mathrm{~min}\right)$ of chokeberry drinks containing cistus, green tea, and nettle extracts significantly reduced the total anthocyanin content. On the other hand, the total polyphenol content in sucrose-sweetened drinks increased, but it did not change in stevia-sweetened drinks [47].

Talcott and co-workers [48] pasteurised $\left(95^{\circ} \mathrm{C}, 15 \mathrm{~min}\right)$ muscadine juice and observed changes in its colour and composition as a result of the co-pigmentation of anthocyanins with the components of an aqueous rosemary extract and ascorbic acid. The rosemary extract additive facilitated the formation of co-pigment complexes with anthocyanins and increased the antioxidative activity. The opposite effect was observed in samples with ascorbic acid and rosemary extract, where the content of anthocyanins, ascorbic acid and antioxidative activity decreased. When ascorbic acid was added to the juices/drinks in our experiment, it reduced the content of catechin and chlorogenic acid in the clarified juices/drinks and the content of cyanidin-3-O-galactoside and cyanidin-3-O-glucoside in the cloudy juices/drinks during pasteurisation. 


\subsection{The Effect of Storage on the Content of Polyphenolic Compounds in Pasteurised Juices/Drinks}

The storage of chokeberry juices caused changes in the composition of polyphenols (Tables 4-6). The degradation of cyanidins was particularly noticeable, as there were undesirable changes in these compounds every month. Changes in the content of polyphenols, especially the degradation of anthocyanins, are typical of stored juices. They depend on the storage time and temperature $[49,50]$. Changes in the content of individual groups of polyphenols in the analysed juices/drinks during storage are presented on Figure 1.

Table 4. Changes in the content of phenolic acids and flavanols during storage of tested juices/drinks.

\begin{tabular}{|c|c|c|c|c|c|}
\hline & \multirow[b]{3}{*}{ Additive } & \multicolumn{4}{|c|}{ Juice/Drink } \\
\hline & & \multicolumn{4}{|c|}{ Storage [Month] } \\
\hline & & 0 & 1st & 2nd & 3 rd \\
\hline \multicolumn{6}{|c|}{$(+)$-catechin $[\mathrm{mg} / 100 \mathrm{~mL}]$} \\
\hline \multirow{5}{*}{ 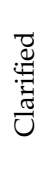 } & No additives & $1.51 \pm 0.09^{B, b, c}$ & $1.96 \pm 0.09 \mathrm{~A}, \mathrm{~b}, \mathrm{c}$ & $2.01 \pm 0.03^{\mathrm{A}, \mathrm{d}}$ & $2.04 \pm 0.07^{\mathrm{A}, \mathrm{bc}}$ \\
\hline & Ascorbic acid & $1.60 \pm 0.03^{C, a, b}$ & $2.91 \pm 0.03^{\mathrm{B}, \mathrm{a}}$ & $3.47 \pm 0.04 \mathrm{~A}, \mathrm{~b}$ & $3.57 \pm 0.08 \mathrm{~A}, \mathrm{a}$ \\
\hline & Cinnamon extract & $1.39 \pm 0.01 \mathrm{C}, \mathrm{c}$ & $1.70 \pm 0.06^{\mathrm{B}, \mathrm{d}}$ & $1.84 \pm 0.02 \mathrm{~A}, \mathrm{e}$ & $1.80 \pm 0.04 \mathrm{~A}, \mathrm{~B}, \mathrm{c}$ \\
\hline & Clove extract & $1.73 \pm 0.04^{\mathrm{B}, \mathrm{a}}$ & $1.99 \pm 0.03 \mathrm{~A}, \mathrm{~b}, \mathrm{c}$ & $2.05 \pm 0.00 \mathrm{~A}, \mathrm{~d}$ & $1.97 \pm 0.11 \mathrm{~A}, \mathrm{~b}, \mathrm{c}$ \\
\hline & No additives & $1.52 \pm 0.06^{\mathrm{C}, \mathrm{b}, \mathrm{c}}$ & $1.87 \pm 0.03^{\mathrm{B}, \mathrm{c}, \mathrm{d}}$ & $2.05 \pm 0.02 \mathrm{~A}, \mathrm{~d}$ & $2.04 \pm 0.06^{\mathrm{A}, \mathrm{b}, \mathrm{c}}$ \\
\hline \multirow{3}{*}{$\begin{array}{l}\vec{z} \\
\frac{0}{\Xi} \\
\frac{0}{U}\end{array}$} & Ascorbic acid & $1.75 \pm 0.09 \mathrm{C}, \mathrm{a}$ & $2.98 \pm 0.08^{\mathrm{B}, \mathrm{a}}$ & $3.69 \pm 0.03 \mathrm{~A}, \mathrm{a}$ & $3.54 \pm 0.26^{\mathrm{A}, \mathrm{a}}$ \\
\hline & Cinnamon extract & $1.48 \pm 0.02^{\mathrm{B}, \mathrm{b}, \mathrm{c}}$ & $1.81 \pm 0.10^{\mathrm{A}, \mathrm{c}, \mathrm{d}}$ & $1.82 \pm 0.01 \mathrm{~A}, \mathrm{e}$ & $1.82 \pm 0.00^{\mathrm{A}, \mathrm{c}}$ \\
\hline & Clove extract & $1.77 \pm 0.11^{\mathrm{B}, \mathrm{a}}$ & $2.09 \pm 0.07^{\mathrm{A}, \mathrm{b}}$ & $2.14 \pm 0.04 \mathrm{~A}, \mathrm{c}^{-}$ & $2.19 \pm 0.13^{\mathrm{A}, \mathrm{b}}$ \\
\hline \multicolumn{6}{|c|}{ (-)-epicatechin $[\mathrm{mg} / 100 \mathrm{~mL}]$} \\
\hline \multirow{5}{*}{ 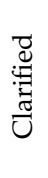 } & No additives & $4.53 \pm 0.07^{\mathrm{A}, \mathrm{c}}$ & $4.39 \pm 0.15^{\mathrm{A}, \mathrm{b}, \mathrm{c}}$ & $4.52 \pm 0.16^{\mathrm{A}, \mathrm{b}}$ & $4.41 \pm 0.18^{\mathrm{A}, \mathrm{a}, \mathrm{b}, \mathrm{c}}$ \\
\hline & Ascorbic acid & $4.53 \pm 0.06^{\mathrm{B}, \mathrm{c}}$ & $4.75 \pm 0.06^{\mathrm{A}, \mathrm{a}}$ & $4.76 \pm 0.06^{\mathrm{A}, \mathrm{a}}$ & $4.83 \pm 0.08^{\mathrm{A}, \mathrm{a}}$ \\
\hline & Cinnamon extract & $4.82 \pm 0.04^{\mathrm{A}, \mathrm{a}}$ & $4.31 \pm 0.08^{\mathrm{B}, \mathrm{c}}$ & $4.26 \pm 0.02^{\mathrm{B}, \mathrm{c}}$ & $4.05 \pm 0.09 \mathrm{C}, \mathrm{c}$ \\
\hline & Clove extract & $4.79 \pm 0.03^{\mathrm{A}, \mathrm{a}, \mathrm{b}}$ & $4.66 \pm 0.03^{\mathrm{A}, \mathrm{B}, \mathrm{a}, \mathrm{b}}$ & $4.52 \pm 0.00^{\mathrm{B}, \mathrm{b}}$ & $4.19 \pm 0.19 \mathrm{C}, \mathrm{b}, \mathrm{c}$ \\
\hline & No additives & $4.66 \pm 0.14^{\mathrm{A}, \mathrm{a}, \mathrm{b}, \mathrm{c}}$ & $4.53 \pm 0.10^{\mathrm{A}, \mathrm{a}, \mathrm{b}, \mathrm{c}}$ & $4.61 \pm 0.03^{\mathrm{A}, \mathrm{a}, \mathrm{b}}$ & $4.35 \pm 0.31^{\mathrm{A}, \mathrm{a}, \mathrm{b}, \mathrm{c}}$ \\
\hline \multirow{3}{*}{ 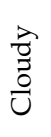 } & Ascorbic acid & $4.60 \pm 0.09 \mathrm{~A}, \mathrm{~b}, \mathrm{c}$ & $4.68 \pm 0.17 \mathrm{~A}, \mathrm{a}, \mathrm{b}$ & $4.73 \pm 0.06^{\mathrm{A}, \mathrm{a}}$ & $4.58 \pm 0.23^{\mathrm{A}, \mathrm{a}, \mathrm{b}}$ \\
\hline & Cinnamon extract & $4.82 \pm 0.05^{\mathrm{A}, \mathrm{a}}$ & $4.45 \pm 0.06^{\mathrm{B}, \mathrm{a}, \mathrm{b}, \mathrm{c}}$ & $4.28 \pm 0.01^{C, c}$ & $4.10 \pm 0.04^{\mathrm{D}, \mathrm{b}, \mathrm{c}}$ \\
\hline & Clove extract & $4.86 \pm 0.02^{\mathrm{A}, \mathrm{a}}$ & $4.55 \pm 0.15^{\mathrm{A}, \mathrm{a}, \mathrm{b}, \mathrm{c}}$ & $4.61 \pm 0.02^{\mathrm{A}, \mathrm{a}, \mathrm{b}}$ & $4.54 \pm 0.19^{\mathrm{A}, \mathrm{a}, \mathrm{b}, \mathrm{c}}$ \\
\hline \multicolumn{6}{|c|}{ neochlorogenic acid $[\mathrm{mg} / 100 \mathrm{~mL}]$} \\
\hline \multirow{4}{*}{ 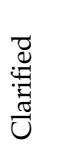 } & No additives & $34.05 \pm 0.56^{\mathrm{A}, \mathrm{a}}$ & $34.02 \pm 0.99 \mathrm{~A}, \mathrm{a}$ & $36.12 \pm 0.39 \mathrm{~A}, \mathrm{a}$ & $34.79 \pm 1.30 \mathrm{~A}, \mathrm{a}$ \\
\hline & Ascorbic acid & $33.86 \pm 0.33^{C, a, b}$ & $36.89 \pm 2.46^{\mathrm{A}, \mathrm{a}}$ & $36.26 \pm 0.30 \mathrm{~A}, \mathrm{~B}, \mathrm{a}$ & $34.92 \pm 1.00^{\mathrm{B}, \mathrm{C}, \mathrm{a}}$ \\
\hline & Cinnamon extract & $31.76 \pm 0.68^{\mathrm{A}, \mathrm{B}, \mathrm{b}, \mathrm{c}}$ & $31.30 \pm 2.89^{\mathrm{B}, \mathrm{a}}$ & $34.50 \pm 0.84^{\mathrm{A}, \mathrm{b}, \mathrm{c}}$ & $33.83 \pm 0.91 \mathrm{~A}, \mathrm{~B}, \mathrm{a}$ \\
\hline & Clove extract & $32.42 \pm 0.63^{\mathrm{A}, \mathrm{a}, \mathrm{b}, \mathrm{c}}$ & $33.04 \pm 2.33^{\mathrm{A}, \mathrm{a}}$ & $35.66 \pm 0.41^{\mathrm{A}, \mathrm{a}, \mathrm{b}}$ & $32.58 \pm 1.31 \mathrm{~A}, \mathrm{a}$ \\
\hline \multirow{4}{*}{$\begin{array}{l}\overrightarrow{0} \\
\text { ठ } \\
\frac{0}{U}\end{array}$} & No additives & $34.19 \pm 0.64 \mathrm{~A}, \mathrm{a}$ & $36.85 \pm 2.88^{\mathrm{A}, \mathrm{a}}$ & $36.72 \pm 0.34 \mathrm{~A}, \mathrm{a}$ & $34.21 \pm 2.27^{\mathrm{A}, \mathrm{a}}$ \\
\hline & Ascorbic acid & $31.22 \pm 1.19 \mathrm{~A}, \mathrm{c}$ & $32.71 \pm 0.09 \mathrm{~A}, \mathrm{a}$ & $33.85 \pm 0.44^{\mathrm{A}, \mathrm{c}, \mathrm{d}}$ & $32.77 \pm 2.03^{\mathrm{A}, \mathrm{a}}$ \\
\hline & Cinnamon extract & $31.87 \pm 0.46^{\mathrm{A}, \mathrm{b}, \mathrm{c}}$ & $32.30 \pm 1.98^{\mathrm{A}, \mathrm{a}}$ & $34.63 \pm 0.25^{\mathrm{A}, \mathrm{b}, \mathrm{c}}$ & $33.56 \pm 0.95 \mathrm{~A}, \mathrm{a}$ \\
\hline & Clove extract & $30.81 \pm 1.06^{\mathrm{A}, \mathrm{c}}$ & $31.40 \pm 3.27 \mathrm{~A}, \mathrm{a}$ & $32.95 \pm 0.43^{\mathrm{A}, \mathrm{d}}$ & $32.63 \pm 0.46^{\mathrm{A}, \mathrm{a}}$ \\
\hline \multicolumn{6}{|c|}{ chlorogenic acid $[\mathrm{mg} / 100 \mathrm{~mL}]$} \\
\hline \multirow{4}{*}{ 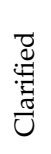 } & No additives & $30.97 \pm 0.35^{\mathrm{A}, \mathrm{a}}$ & $30.82 \pm 0.33 \mathrm{~A}, \mathrm{~B}, \mathrm{a}, \mathrm{b}$ & $30.32 \pm 0.12^{\mathrm{A}, \mathrm{B}, \mathrm{a}, \mathrm{b}}$ & $29.28 \pm 1.09 \mathrm{~A}, \mathrm{~B}, \mathrm{a}, \mathrm{b}$ \\
\hline & Ascorbic acid & $30.82 \pm 0.34^{\mathrm{A}, \mathrm{B}, \mathrm{a}}$ & $31.20 \pm 0.02 \mathrm{~A}, \mathrm{a}$ & $30.74 \pm 0.23 \mathrm{~A}, \mathrm{~B}, \mathrm{a}$ & $29.94 \pm 0.73^{\mathrm{B}, \mathrm{a}}$ \\
\hline & Cinnamon extract & $28.98 \pm 0.27 \mathrm{~A}, \mathrm{~b}$ & $27.78 \pm 0.44^{\mathrm{B}, \mathrm{d}, \mathrm{e}}$ & $29.04 \pm 0.26^{\mathrm{A}, \mathrm{c}}$ & $28.46 \pm 0.52 \mathrm{~A}, \mathrm{~B}, \mathrm{a}, \mathrm{b}$ \\
\hline & Clove extract & $30.08 \pm 0.46^{\mathrm{A}, \mathrm{a}, \mathrm{b}}$ & $29.51 \pm 1.12^{\mathrm{A}, \mathrm{a}, \mathrm{b}, \mathrm{c}}$ & $29.98 \pm 0.16^{\mathrm{A}, \mathrm{b}}$ & $27.96 \pm 1.24 \mathrm{~A}, \mathrm{a}, \mathrm{b}$ \\
\hline \multirow{4}{*}{$\begin{array}{l}\overrightarrow{0} \\
\frac{0}{U} \\
\text { Un }\end{array}$} & No additives & $31.15 \pm 0.64^{\mathrm{A}, \mathrm{a}}$ & $30.79 \pm 0.61 \mathrm{~A}, \mathrm{~B}, \mathrm{a}, \mathrm{b}$ & $30.77 \pm 0.08^{\mathrm{A}, \mathrm{B}, \mathrm{a}}$ & $29.38 \pm 0.89^{\mathrm{B}, \mathrm{a}, \mathrm{b}}$ \\
\hline & Ascorbic acid & $28.93 \pm 0.35^{\mathrm{A}, \mathrm{b}}$ & $28.95 \pm 0.54^{\mathrm{A}, \mathrm{c}, \mathrm{d}}$ & $28.38 \pm 0.21 \mathrm{~A}, \mathrm{~d}$ & $27.21 \pm 1.73^{\mathrm{A}, \mathrm{a}, \mathrm{b}}$ \\
\hline & Cinnamon extract & $29.25 \pm 0.32 \mathrm{~A}, \mathrm{~b}$ & $29.48 \pm 0.34^{\mathrm{A}, \mathrm{b}, \mathrm{c}}$ & $28.84 \pm 0.08^{\mathrm{A}, \mathrm{B}, \mathrm{c}, \mathrm{d}}$ & $27.98 \pm 0.79^{\mathrm{B}, \mathrm{a}, \mathrm{b}}$ \\
\hline & Clove extract & $27.28 \pm 0.54^{\mathrm{A}, \mathrm{c}}$ & $27.17 \pm 0.71^{\mathrm{A}, \mathrm{e}}$ & $27.14 \pm 0.19 \mathrm{~A}, \mathrm{e}$ & $26.82 \pm 0.44^{\mathrm{A}, \mathrm{b}}$ \\
\hline
\end{tabular}

$\mathrm{a}, \mathrm{b}, \mathrm{c}, \mathrm{d}, \mathrm{e}-$ means in a column followed by the same small letter are not significantly different $(p>0.05) ; \mathrm{A}, \mathrm{B}, \mathrm{C}$, $\mathrm{D}-$ means in a row followed by the same capital letter are not significantly different $(p>0.05)$; values are means of three determinations $\pm \mathrm{SD}$ 
Table 5. Changes in flavonol content during storage of tested juices/drinks.

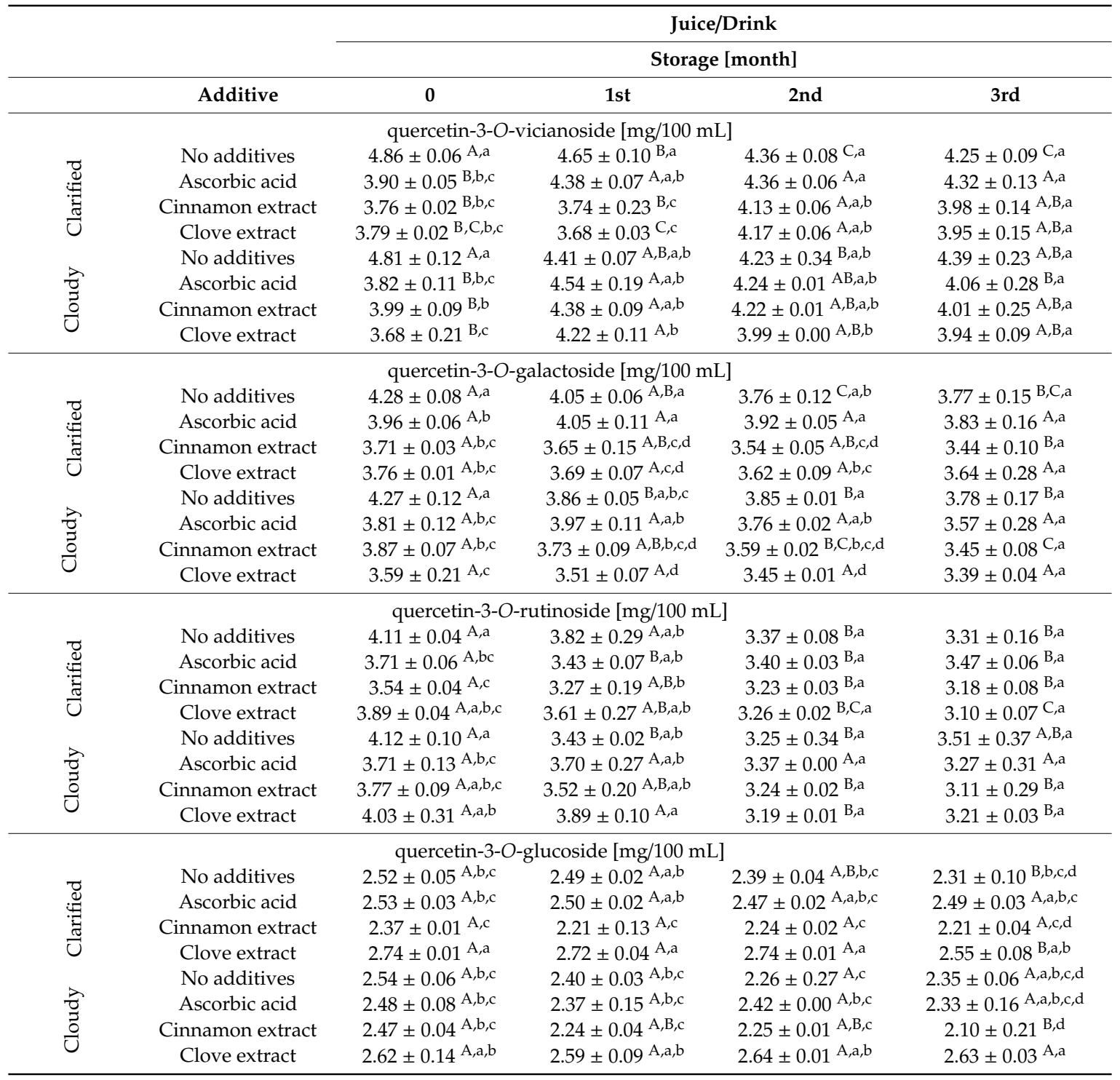

a, b, c, d-means in a column followed by the same small letter are not significantly different $(p>0.05) ; \mathrm{A}, \mathrm{B}$, C-means in a row followed by the same capital letter are not significantly different $(p>0.05)$; values are means of three determinations $\pm \mathrm{SD}$.

Table 6. Changes in anthocyanin content during storage of tested juices/drinks.

\begin{tabular}{|c|c|c|c|c|c|}
\hline & \multirow[b]{2}{*}{ Additive } & \multicolumn{4}{|c|}{ Juice/Drink } \\
\hline & & 0 & 1st & 2nd & 3rd \\
\hline \multicolumn{6}{|c|}{ cyaniding-3-O-galactoside $[\mathrm{mg} / 100 \mathrm{~mL}]$} \\
\hline \multirow{2}{*}{ 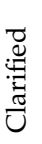 } & No additives & $73.93 \pm 2.32 \mathrm{~A}, \mathrm{a}, \mathrm{b}$ & $46.98 \pm 0.95^{\mathrm{B}, \mathrm{a}, \mathrm{b}}$ & $32.43 \pm 4.45^{\mathrm{C}, \mathrm{a}, \mathrm{b}}$ & $23.83 \pm 2.25^{\mathrm{D}, \mathrm{a}, \mathrm{b}}$ \\
\hline & Ascorbic acid & $74.33 \pm 1.45^{\mathrm{A}, \mathrm{a}, \mathrm{b}}$ & $30.68 \pm 0.51^{\mathrm{B}, \mathrm{e}}$ & $14.57 \pm 2.81^{\mathrm{C}, \mathrm{d}}$ & $10.96 \pm 3.09 \mathrm{C,c}$ \\
\hline \multirow{4}{*}{$\frac{\overrightarrow{0}}{\frac{\partial}{0}}$} & No additives & $76.91 \pm 1.92 \mathrm{~A}, \mathrm{a}$ & $50.33 \pm 0.81^{\mathrm{B}, \mathrm{a}}$ & $36.30 \pm 1.34^{\mathrm{C}, \mathrm{a}}$ & $25.01 \pm 5.83^{\mathrm{D}, \mathrm{a}}$ \\
\hline & Ascorbic acid & $69.58 \pm 0.46^{\mathrm{A}, \mathrm{b}, \mathrm{c}}$ & $33.76 \pm 2.03^{\mathrm{B}, \mathrm{e}}$ & $9.48 \pm 1.84^{\mathrm{C}, \mathrm{d}}$ & $6.87 \pm 1.90^{\mathrm{C}, \mathrm{c}}$ \\
\hline & Cinnamon extract & $64.10 \pm 2.30 \mathrm{~A}, \mathrm{c}$ & $41.40 \pm 0.63^{\mathrm{B}, \mathrm{c}, \mathrm{d}}$ & $24.17 \pm 0.50 \mathrm{C}, \mathrm{c}$ & $15.77 \pm 0.82^{\mathrm{D}, \mathrm{a}, \mathrm{b}, \mathrm{c}}$ \\
\hline & Clove extract & $66.07 \pm 4.08^{\mathrm{A}, \mathrm{c}}$ & $43.86 \pm 2.65^{\mathrm{B}, \mathrm{b}, \mathrm{c}}$ & $30.07 \pm 4.08^{\mathrm{C}, \mathrm{a}, \mathrm{b}, \mathrm{c}}$ & $22.10 \pm 7.32^{\mathrm{C}, \mathrm{a}, \mathrm{b}}$ \\
\hline
\end{tabular}


Table 6. Cont.

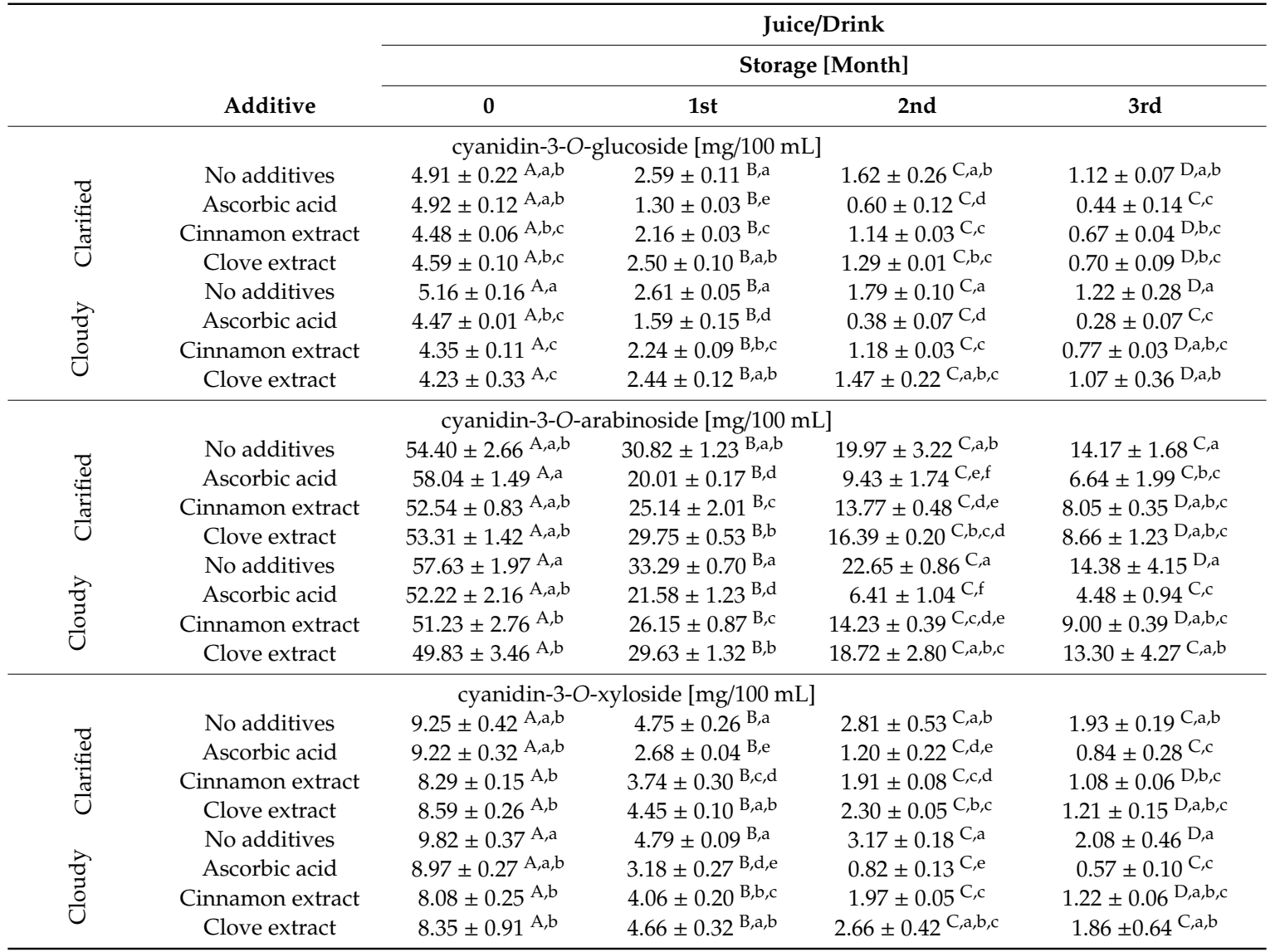

$\mathrm{a}, \mathrm{b}, \mathrm{c}, \mathrm{d}, \mathrm{e}, \mathrm{f}-\mathrm{means}$ in a column followed by the same small letter are not significantly different $(p>0.05)$; A, B, C, $\mathrm{D}-$ means in a row followed by the same capital letter are not significantly different $(p>0.05)$; values are means of three determinations $\pm \mathrm{SD}$.

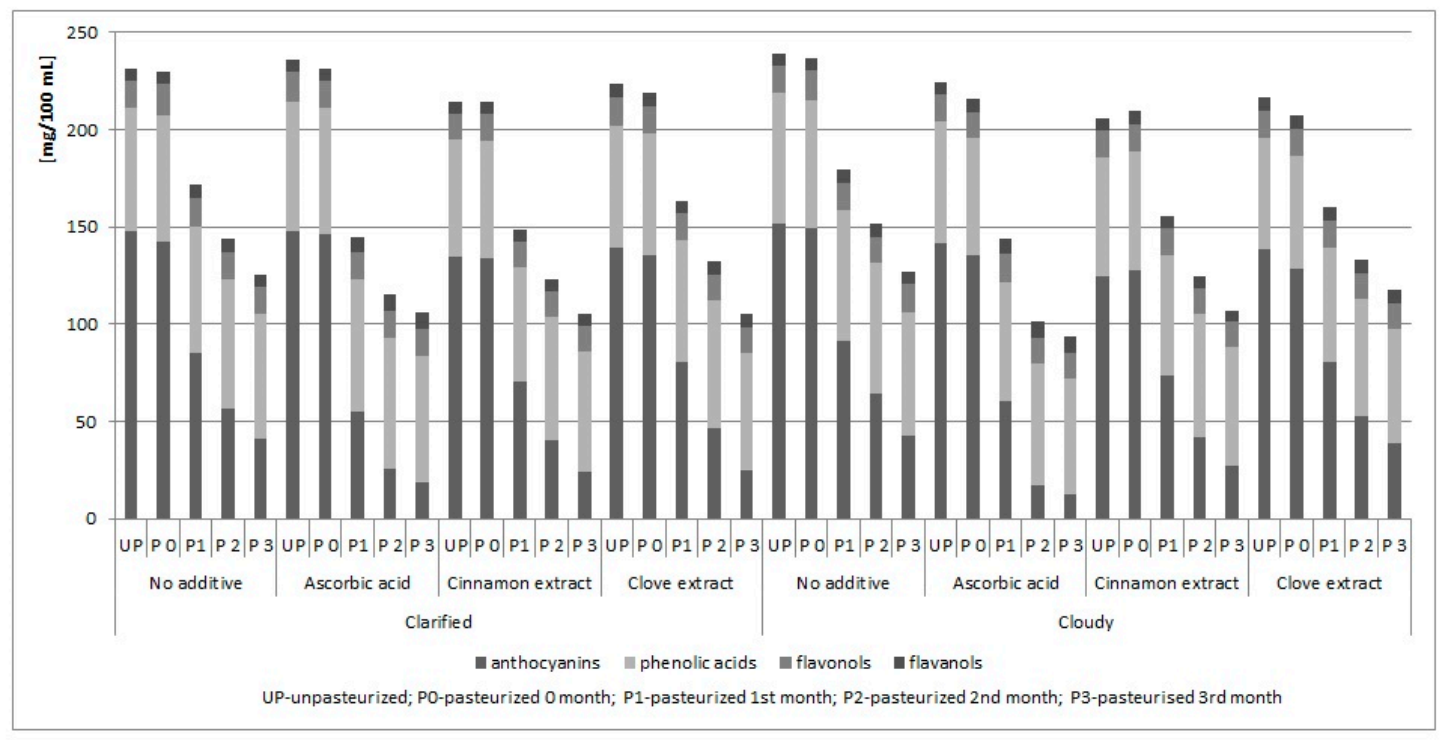

Figure 1. Changes in the content of individual groups of polyphenols in the analysed juices/drinks during storage.

To illustrate the influence of the additive on the degree of degradation of anthocyanins, the reaction rate constant $k$ for the first-order reaction was determined and the half-life $t_{1 / 2}$ was calculated. The half-life showed that ascorbic acid and the spice plant extracts accelerated the degradation of 
anthocyanins in the juices (Table 7). Fresh chokeberry juice has high polyphenol content, which is related to potential health-promoting effect; however, processing and storage could often influence polyphenols losses. Ascorbic acid caused the greatest degradation of cyanidins. Among the juices with the extracts, only the clove extract extended the half-life of cyanidins in the cloudy juices. The most stable cyanidins were cyanidin-3-O-galactoside, followed by cyanidin-3-O-arabinoside, glucoside, and xyloside. The degradation of individual cyanidins occurred more rapidly in the clarified juices, except for the juices with ascorbic acid. The degradation of cyanidin-3-O-arabinoside occurred faster in the juices without additives. After three months of storage the anthocyanins loss level ranged from $66.6 \%$ for cyanidin-3-O-galactoside in the cloudy juice with the clove extract to $82.77 \%$ for cyanidin-3-O-glucoside in the cloudy juice with ascorbic acid.

Table 7. Equation of the curve for degradation, constant reaction rate and half-life of anthocyanins in chokeberry juices.

\begin{tabular}{|c|c|c|c|c|c|}
\hline & Juice/Drink & $\begin{array}{c}\text { Equation for the Curve of } \\
\text { the Logarithm of } \\
\text { Substrate Concentration } \\
\text { versus Time } t[\mathrm{~d}] \text { for } \\
\text { First-Order Reactions }\end{array}$ & $\mathbf{R}^{2}$ & $k\left[\mathrm{~d}^{-1}\right]$ & $t_{1 / 2}[d]$ \\
\hline \multirow{5}{*}{ 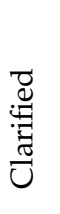 } & & cyanidin-3-O-galactoside & & & \\
\hline & No additives & $y=-0.0055 x+1.8526$ & 0.9926 & $5.5 \times 10^{-3}$ & 126.0 \\
\hline & Ascorbic acid & $y=-0.0094 x+1.8129$ & 0.9567 & $9.4 \times 10^{-3}$ & 73.7 \\
\hline & Cinnamon extract & $y=-0.0076 x+1.8290$ & 0.9995 & $7.6 \times 10^{-3}$ & 91.2 \\
\hline & Clove extract & $y=-0.0076 x+1.8558$ & 0.9957 & $7.6 \times 10^{-3}$ & 91.2 \\
\hline \multirow{4}{*}{$\begin{array}{l}\frac{i}{0} \\
\frac{0}{0} \\
\end{array}$} & No additives & $y=-0.0054 x+1.8773$ & 0.9975 & $5.4 \times 10^{-3}$ & 128.3 \\
\hline & Ascorbic acid & $y=-0.0119 x+1.8314$ & 0.9570 & $11.9 \times 10^{-3}$ & 58.2 \\
\hline & Cinnamon extract & $y=-0.0069 x+1.8103$ & 0.9980 & $6.9 \times 10^{-3}$ & 100.4 \\
\hline & Clove extract & $y=-0.0053 x+1.8097$ & 0.9960 & $5.3 \times 10^{-3}$ & 130.8 \\
\hline \multirow{5}{*}{ 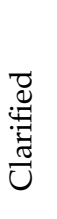 } & & cyanidin-3-O-glucoside & & & \\
\hline & No additives & $y=-0.0071 x+0.6602$ & 0.9852 & $7.1 \times 10^{-3}$ & 97.6 \\
\hline & Ascorbic acid & $y=-0.0116 x+0.5786$ & 0.9244 & $11.6 \times 10^{-3}$ & 59.7 \\
\hline & Cinnamon extract & $y=-0.0092 x+0.6300$ & 0.9950 & $9.2 \times 10^{-3}$ & 75.3 \\
\hline & Clove extract & $y=-0.0091 x+0.6645$ & 0.9998 & $9.1 \times 10^{-3}$ & 76.2 \\
\hline \multirow{4}{*}{$\begin{array}{l}\frac{\lambda}{0} \\
\frac{0}{0} \\
\frac{0}{U}\end{array}$} & No additives & $y=-0.0068 x+0.6733$ & 0.9755 & $6.8 \times 10^{-3}$ & 101.9 \\
\hline & Ascorbic acid & $y=-0.0142 x+0.6062$ & 0.9537 & $14.2 \times 10^{-3}$ & 48.8 \\
\hline & Cinnamon extract & $y=-0.0085 x+0.6175$ & 0.9912 & $8.5 \times 10^{-3}$ & 81.5 \\
\hline & Clove extract & $y=-0.0067 x+0.6043$ & 0.9871 & $6.7 \times 10^{-3}$ & 103.4 \\
\hline \multirow{6}{*}{ 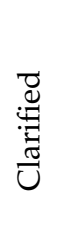 } & & cyanidin-3-O-arabinoside & & & \\
\hline & No additives & $y=-0.0065 x+1.7102$ & 0.9874 & $6.5 \times 10^{-3}$ & 106.6 \\
\hline & Ascorbic acid & $y=-0.0105 x+1.6880$ & 0.9536 & $10.5 \times 10^{-3}$ & 66.0 \\
\hline & Cinnamon extract & $y=-0.0090 x+1.6972$ & 0.9947 & $9.0 \times 10^{-3}$ & 77.0 \\
\hline & Clove extract & $y=-0.0088 x+1.7321$ & 0.9996 & $8.8 \times 10^{-3}$ & 78.8 \\
\hline & No additives & $y=-0.0066 x+1.7454$ & 0.9953 & $6.6 \times 10^{-3}$ & 105.0 \\
\hline \multirow{3}{*}{$\begin{array}{l}\frac{2}{0} \\
\frac{0}{0} \\
\frac{0}{u}\end{array}$} & Ascorbic acid & $y=-0.0124 x+1.6865$ & 0.9635 & $12.4 \times 10^{-3}$ & 55.9 \\
\hline & Cinnamon extract & $y=-0.0084 x+1.6881$ & 0.9930 & $8.4 \times 10^{-3}$ & 82.5 \\
\hline & Clove extract & $y=-0.0064 x+1.6794$ & 0.9918 & $6.4 \times 10^{-3}$ & 108.3 \\
\hline \multirow{5}{*}{ 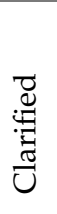 } & & cyanidin-3-O-xyloside & & & \\
\hline & No additives & $y=-0.0076 x+0.9343$ & 0.9343 & $7.6 \times 10^{-3}$ & 91.2 \\
\hline & Ascorbic acid & $y=-0.0116 x+0.8695$ & 0.9430 & $11.6 \times 10^{-3}$ & 59.7 \\
\hline & Cinnamon extract & $y=-0.0098 x+0.8939$ & 0.9947 & $9.8 \times 10^{-3}$ & 70.7 \\
\hline & Clove extract & $y=-0.0095 x+0.9329$ & 1.000 & $9.5 \times 10^{-3}$ & 72.9 \\
\hline \multirow{4}{*}{$\begin{array}{l}\frac{2}{0} \\
\frac{0}{0} \\
\frac{0}{0}\end{array}$} & No additives & $y=-0.0073 x+0.9528$ & 0.9794 & $7.3 \times 10^{-3}$ & 94.9 \\
\hline & Ascorbic acid & $y=-0.0139 x+0.9083$ & 0.9593 & $13.9 \times 10^{-3}$ & 49.9 \\
\hline & Cinnamon extract & $y=-0.0093 x+0.8911$ & 0.9929 & $9.3 \times 10^{-3}$ & 74.5 \\
\hline & Clove extract & $y=-0.0073 x+0.9010$ & 0.9894 & $7.3 \times 10^{-3}$ & 94.9 \\
\hline
\end{tabular}


After slightly more than 3 months of storage of blueberry and chokeberry nectar, there were considerable losses of anthocyanins observed, i.e., cyanidin-3-O-galactoside- $67.3 \%$, cyanidin-3-O-glucoside-66.1\%, and cyanidin-3-O-arabinoside-74.6\% [51]. The research by Wilkes with colleagues [43], who studied the influence of storage time on the losses of cyanidins in chokeberry juice, showed that the changes were less intense. After three months of storage, the content of cyanidin-3-O-galactoside, glucoside and arabinoside in the juice decreased by over $30 \%$, whereas the content of cyanidin-3-O-xyloside decreased by about $26 \%$.

Substances made from plants do not always prevent the loss of polyphenols. Stevia, with which chokeberry juices were sweetened, was an additional source of polyphenols, including flavonoids and phenolic acids. During 60-day storage, the losses of total polyphenols, flavonoids and cyanidin-3-O-glycosides in juices with stevia were greater than the losses in sucrose-sweetened juice [52]. Extracts of various origins had different effect on the retention of anthocyanins in blackberry juice. $0.1 \%$ extracts added to the juice increased the total anthocyanin content by $2 \%$. During the storage of juices for 52 days there was a loss of anthocyanins observed. In comparison with juice without an additive $(119.85 \mathrm{mg} / \mathrm{L})$, juices with an olive leaf and pine bark extract PE 5:1 or bioflavonoids contained less anthocyanins (103.44-114.21 mg/L). The content of anthocyanins in juices with the red wine extract PE 4:1 was at a comparable level $(118.84 \mathrm{mg} / \mathrm{L})$, but it was greater in the extracts with green tea, pine bark PE 95\% and red wine PE 30\% (131.99-135.57 mg/L) [53]. The storage of wine causes losses of monomeric anthocyanins and the formation of polymeric pigments mainly between anthocyanins and proanthocyanins. The addition of Origanum vulgare and Satureja thymbra extracts or rosmarinic acid to wine resulted in the formation of co-pigments, but it did not affect the rate of polymerisation [54].

Plant extracts were added to cherry juice concentrate to improve and increase its colour stability during storage. The addition of pomegranate rind extract or green tea extract increased the stability of the main anthocyanins: cyanidin-3-O-glucosylrutinoside, cyanidin-3-O-rutinoside and cyanidin-3-O-sophoroside. The cherry stem extract reduced the stability of anthocyanins in the concentrate during storage for 110 days [55].

When ascorbic acid was added to the chokeberry juices, it accelerated degradation. The half-life values were $34.5-41.5 \%$ lower than in the juices without the additive. The rate of degradation of anthocyanins depends on the concentration of ascorbic acid, the $\mathrm{pH}$ of the environment and temperature. The concentration of anthocyanins in sweet potato decreased as the concentration of ascorbic acid increased, and it was clearly noticeable at $25^{\circ} \mathrm{C}$ [56]. Farr and Giusti [57] noted high values of $t_{1 / 2}=858 \mathrm{~h}$ for the anthocyanin chokeberry extract. When ascorbic acid was added at amounts of 250, 500, and 1000 $\mathrm{mg} / \mathrm{L}$, it accelerated the degradation of anthocyanins in the extract, which resulted in lower half-life values, i.e., $t_{1 / 2}=68,43$ and $24 \mathrm{~h}$, respectively. When $\mathrm{pH}$ was reduced, it stabilised anthocyanins in the presence of ascorbic acid [58]. The $\mathrm{pH}$ of the juices/drinks tested in the study $(\mathrm{pH}=3.42-3.52)$ favoured the stability of anthocyanins and polyphenols (unpublished data). According to Farr and Giusti [57], the reactivity of ascorbic acid with C-4 carbon in anthocyanins is the mechanism catalysing their degradation. When cyanidin-3-O-galactoside was synthesised with pyruvic acid, the resulting product was pyranoanthocyanin with blocked C-4 carbon. The half-lives of the tested compounds combined with ascorbic acid at various concentrations were as follows: 5-carboxypyranocyanidin-3-galactoside > chokeberry extract $>$ cyanidin-3-O-galactoside. This suggests that C-4 carbon plays an important role in the degradation of anthocyanins under the influence of ascorbic acid. However, the example of the chokeberry extract, whose main anthocyanin is cyanidin-3-O-galactoside, shows that this is not the only mechanism. It is very likely that the other polyphenols contained in the extract also limited the degradation of anthocyanins.

The protective effect of other polyphenols could be explained by the research conducted by Stebbins et al. [59]. The authors observed that cyanidin-3-O- $\beta$-glucoside and malvidin-3-O- $\beta$-glucoside were oxidised into 6-hydroxy forms in the presence of ascorbic acid. They suggested that the formation of 6-hydroxy-cyanidin3-O- $\beta$-glucoside and 6-hydroxy-malvidin-3-O- $\beta$-glucoside occurred under the 
influence of hydroxyl radicals $\left(\mathrm{HO}^{\bullet}\right)$ generated by the Haber-Weiss reaction, in which ascorbic acid is involved. Electron spin resonance (ESR) analysis in systems with blackberry extract and cyanidin-3-O- $\beta$-glucoside showed the protective role of other polyphenols contained in the extract, which scavenged hydroxyl radicals $\left(\mathrm{HO}^{\bullet}\right)$.

The protective effect of polyphenols may come from other sources. Roidoung, Dolan and Siddiq [60] added gallic acid to cranberry juice enriched with ascorbic acid and observed lower loss of anthocyanins. On the other hand, it is necessary to select the right raw material and antioxidants to achieve the desired effect. Otherwise, inadequate combinations may provide little or no protection to anthocyanins. Gérard and co-workers [61] studied antioxidants in the form of seven pure compounds and two extracts with strong antioxidative effect, i.e., green coffee bean extract and rosemary extract. The anthocyanin extracts of black carrot, grape juice and purple sweet potato to which $200 \mathrm{mg} / \mathrm{L}$ ascorbic acid was added were very slightly stabilised only by chlorogenic acid, sinapic acid, fumaric acid, and $\beta$-carotene. There is a study indicating the benefits of using ascorbic acid as an additive. The storage of sour cherry concentrate with ascorbic acid limited the degradation of anthocyanins at temperatures of $4{ }^{\circ} \mathrm{C}$ and $24^{\circ} \mathrm{C}$, but at $45^{\circ} \mathrm{C}$ it sharply reduced their concentration [62].

\section{Conclusions}

Fresh chokeberry juice has high polyphenol content, which is related to its potential health-promoting effect; however, processing and storage can often influence polyphenol losses. Our study was an attempt to reduce the loss of polyphenol in chokeberry juice by adding aqueous cinnamon and clove extracts. The clarification of the juices did not cause significant changes in the concentration of polyphenols. The addition of the extracts decreased the content of phenolic acids in the cloudy juices. The pasteurisation of the juices usually did not cause changes in the composition of polyphenols, but the cinnamon and clove extracts caused significant differences in the content of flavonols. The degradation of anthocyanins was the main change in the composition of the chokeberry juices observed during storage. Half-life $\left(t_{1 / 2}\right)$ was used to determine the potential protective influence of the extracts on cyanidin. It showed that the spice plant extracts used as additives accelerated the degradation of anthocyanins in the juices, except the clove extract added to the cloudy juices, which extended the half-life of the cyanidins analysed in the study. The research results showed that despite the common view about the beneficial effects of polyphenols and other compounds exhibiting antioxidative potential to each other, it is very difficult to achieve protection from degradation. Further research is necessary to investigate this problem.

Author Contributions: A.S. (Andrzej Sidor), conceptualisation, methodology, formal analysis, investigation, writing, and editing; A.D., formal analysis, methodology; A.B., formal analysis, methodology; A.S. (Artur Szwengiel) formal analysis; and A.G.-M., conceptualisation, investigation, editing, supervision, and funding acquisition. All authors have read and agreed to the published version of the manuscript.

Funding: The was publication co-financed within the framework of Ministry of Science and Higher Education program as "Regional Initiative Excellence" in the years 2019-2022, project number 005/RID/2018/19.

Conflicts of Interest: The authors declare no conflict of interest.

\section{References}

1. Borowska, S.; Brzóska, M.M. Chokeberries (Aronia melanocarpa) and their products as a possible means for the prevention and treatment of noncommunicable diseases and unfavorable health effects due to exposure to xenobiotics. Compr. Rev. Food Sci. Food Saf. 2016, 15, 982-1017. [CrossRef]

2. Sidor, A.; Gramza-Michałowska, A. Black chokeberry Aronia melanocarpa L.-A qualitative composition, phenolic profile and antioxidant potential. Molecules 2019, 24, 3710. [CrossRef] [PubMed]

3. Kawecki, Z.; Tomaszewska, Z. The effect of various soil management techniques on growth and yield in the black chokeberry (Aronia melanocarpa Elliot). J. Fruit Ornam. Plant Res. 2006, 14, 67-73.

4. Strik, B.; Finn, C.; Wrolstad, R. Performance of Chokeberry (Aronia Melanocarpa) in Oregon, USA. Acta Hortic. 2003, 626, 439-443. [CrossRef] 
5. Jurikova, T.; Mlcek, J.; Skrovankova, S.; Sumczynski, D.; Sochor, J.; Hlavacova, I.; Snopek, L.; Orsavova, J. Fruits of black chokeberry Aronia melanocarpa in the prevention of chronic diseases. Molecules 2017, 22, 944. [CrossRef] [PubMed]

6. Broncel, M.; Kozirog, M.; Duchnowicz, P.; Koter-Michalak, M.; Sikora, J.; Chojnowska-Jezierska, J. Aronia melanocarpa extract reduces blood pressure, serum endothelin, lipid, and oxidative stress marker levels in patients with metabolic syndrome. Med. Sci. Monit. 2010, 16, 28-34.

7. Kardum, N.; Milovanović, B.; Šavikin, K.; Zdunić, G.; Mutavdžin, S.; Gligorijević, T.; Spasić, S. Beneficial effects of polyphenol-rich chokeberry juice consumption on blood pressure level and lipid status in hypertensive subjects. J. Med. Food 2015, 18, 1231-1238. [CrossRef] [PubMed]

8. Naruszewicz, M.; Łaniewska, I.; Millo, B.; Dłużniewski, M. Combination therapy of statin with flavonoids rich extract from chokeberry fruits enhanced reduction in cardiovascular risk markers in patients after myocardial infraction (MI). Atherosclerosis 2007, 194, 179-184. [CrossRef]

9. Poreba, R.; Skoczynska, A.; Gac, P.; Poreba, M.; Jedrychowska, I.; Affelska-Jercha, A.; Turczyn, B.; Wojakowska, A.; Oszmianski, J.; Andrzejak, R. Drinking of chokeberry juice from the ecological farm Dzieciolowo and distensibility of brachial artery in men with mild hypercholesterolemia. Ann. Agric. Environ. Med. 2009, 16, 305-308.

10. Sikora, J.; Broncel, M.; Markowicz, M.; Chałubiński, M.; Wojdan, K.; Mikiciuk-Olasik, E. Short-term supplementation with Aronia melanocarpa extract improves platelet aggregation, clotting, and fibrinolysis in patients with metabolic syndrome. Eur. J. Nutr. 2011, 51, 549-556. [CrossRef]

11. Sikora, J.; Broncel, M.; Mikiciuk-Olasik, E. Aronia melanocarpa Elliot reduces the activity of angiotensin I-converting enzyme-In vitro and ex vivo studies. Oxid. Med. Cell. Longev. 2014, 2014, 739721. [CrossRef] [PubMed]

12. Skoczyńska, A.; Jędrychowska, I.; Poręba, R.; Affelska-Jercha, A.; Turczyn, B.; Wojakowska, A.; Andrzejak, R. Influence of chokeberry juice on arterial blood pressure and lipid parameters in men with mild hypercholesterolemia. Pharmacol. Rep. 2007, 59, 177-182.

13. Tolić, M.T.; Krbavčić, I.P.; Vujević, P.; Milinović, B.; Jurčević, I.L.; Vahčić, N. Effects of weather conditions on phenolic content and antioxidant capacity in juice of chokeberries (Aronia melanocarpa L.). Pol. J. Food Nutr. Sci. 2017, 67, 67-74.

14. Kitryte, V.; Kraujaliene, V.; Sulniute, V.; Pukalskas, A.; Rimantas Venskutonis, P. Chokeberry pomace valorization into food ingredients by enzyme-assisted extraction: Process optimization and product characterization. Food Bioprod. Process. 2017, 105, 36-50. [CrossRef]

15. Zhang, C.; Fan, L.; Fan, S.; Wang, J.; Luo, T.; Tang, Y.; Chen, Z.; Yu, L. Cinnamomum cassia Presl: A review of its traditional uses, phytochemistry, pharmacology and toxicology. Molecules 2019, 24, 3473. [CrossRef]

16. Kaur, K.; Kaushal, S. Phytochemistry and pharmacological aspects of Syzygium aromaticum: A review. J. Pharmacogn. Phytochem. 2019, 8, 398-406.

17. Cortés-Rojas, D.F.; Souza, C.R.; Oliveira, W.P. Clove (Syzygium aromaticum): A precious spice. Asian Pac. J. Trop. Biomed. 2014, 4, 90-96. [CrossRef]

18. Vallverdú-Queralt, A.; Regueiro, J.; Martínez-Huélamo, M.; Alvarenga, J.F.; Leal, L.N.; Lamuela-Raventos, R.M. A Comprehensive study on the phenolic profile of widely used culinary herbs and spices: Rosemary, thyme, oregano, cinnamon, cumin and bay. Food Chem. 2014, 154, 299-307. [CrossRef]

19. Luo, Q.; Wang, S.; Lu, Q.; Luo, J.; Cheng, Y. Identification of compounds from the water soluble extract of cinnamomum cassia barks and their inhibitory effects against high-glucose-induced mesangial cells. Molecules 2013, 18, 10930-10943. [CrossRef]

20. Al-Numair, K.S.; Ahmad, D.; Ahmed, S.B.; Al-Assaf, A.H. Nutritive value, levels of polyphenols and anti-nutritional factors in Sri Lankan cinnamon (Cinnamomum Zeyalnicum) and Chinese Cinnamon (Cinnamomum Cassia). Food Sci. Agric. Res. Cent. King Saud Univ. 2007, 154, 5-21.

21. Kalvėnienè, Z.; Velžienė, S.; Ramanauskienè, K.; Savickas, A.; Ivanauskas, L.; Brusokas, V. The qualitative analysis of ethanol extracts of herbal raw materials by method of high pressure liquid chromatography. Acta Pol. Pharm. Drug Res. 2007, 64, 327-333.

22. Sanae, F.; Kamiyama, O.; Ikeda-Obatake, K.; Higashi, Y.; Asano, N.; Adachi, I.; Kato, A. Effects of eugenol-reduced clove extract on glycogen phosphorylase $\mathrm{b}$ and the development of diabetes in $\mathrm{db} / \mathrm{db}$ mice. Food Funct. 2014, 5, 214-219. [CrossRef] [PubMed] 
23. Kim, J.; Seo, C.; Kim, S.; Ha, H. Simultaneous Determination of gallic acid, ellagic acid, and eugenol in Syzygium aromaticum and verification of chemical antagonistic effect by the combination with curcuma aromatica using regression analysis. J. Anal. Methods Chem. 2013, 2013, 375294. [CrossRef]

24. Rastogi, S.; Pandey, M.M.; Rawat, A.K. High-Performance Thin-Layer chromatography densitometric method for the simultaneous determination of three phenolic acids in Syzygium aromaticum (L.) Merr. \& Perry. J. AOAC Int. 2008, 91, 1169-1173.

25. Polish Committee for Standardization. PN-R-75032:1996 Aronia (Black Chokeberry); Polish Committee for Standardization: Warsaw, Poland, 1996.

26. Gülçin, İ.; Şat, İ.G.; Beydemir, Ş.; Elmastaş, M.; Küfrevioğlu, Ö.İ. Comparison of antioxidant activity of clove (Eugenia caryophylata Thunb) buds and lavender (Lavandula stoechas L.). Food Chem. 2004, 87, 393-400.

27. Jarosz, M. Normy Żywienia dla Populacji Polski [Nutrition Standards for the Polish Population]; National Food and Nutrition Institute: Warsaw, Poland, 2017.

28. Valcheva-Kuzmanova, S.; Stavreva, G.; Dancheva, V.; Terziev, L.; Atanasova, M.; Stoyanova, A.; Dimitrova, A.; Shopova, V. Effect of Aronia melanocarpa fruit juice on amiodarone-induced pneumotoxicity in rats. Pharmacogn. Mag. 2014, 10, 132. [CrossRef] [PubMed]

29. Lachowicz, S.; Oszmiański, J.; Pluta, S. The composition of bioactive compounds and antioxidant activity of Saskatoon berry (Amelanchier alnifolia Nutt.) genotypes grown in central Poland. Food Chem. 2017, 235, 234-243. [CrossRef] [PubMed]

30. Ochmian, I.; Grajkowski, J.; Smolik, M. Comparsion of some morphological features, quality and chemical content of four cultivars of chokeberry fruits (Aronia melanocarpa). Not. Bot. Horti Agrobot. Cluj-Napoca 2012, 40, 253-260. [CrossRef]

31. Ochmian, I.; Oszmiański, J.; Skupień, K. Chemical composition, phenolics and firmness of small black fruis. J. Appl. Bot. Food Qual. 2009, 83, 64-69.

32. Kardum, N.; Takić, M.; Šavikin, K.; Zec, M.; Zdunić, G.; Spasić, S.; Konić-Ristić, A. Effects of polyphenol-rich chokeberry juice on cellular antioxidant enzymes and membrane lipid status in healthy women. J. Funct. Foods 2014, 9, 89-97. [CrossRef]

33. Mayer-Miebach, E.; Adamiuk, M.; Behsnilian, D. Stability of chokeberry bioactive polyphenols during juice processing and stabilization of a polyphenol-rich material from the by-product. Agriculture 2012, 2, 244-258. [CrossRef]

34. Tarko, T.; Duda-Chodak, A.; Sroka, P.; Satora, P.; Michalik, J. Transformations of phenolic compounds in an in vitro model simulating the human alimentary tract. Food Technol. Biotechnol. 2009, 47, 456-463.

35. Jurgoński, A.; Juśkiewicz, J.; Zduńczyk, Z. Ingestion of black chokeberry fruit extract leads to intestinal and systemic changes in a rat model of prediabetes and hyperlipidemia. Plant Foods Hum. Nutr. 2008, 63, 176-182. [CrossRef] [PubMed]

36. Oszmiański, J.; Wojdylo, A. Aronia melanocarpa phenolics and their antioxidant activity. Eur. Food Res. Technol. 2005, 221, 809-813. [CrossRef]

37. Rauf, A.; Imran, M.; Abu-Izneid, T.; Patel, S.; Pan, X.; Naz, S.; Sanches Silva, A.; Saeed, F.; Rasul Suleria, H.A. Proanthocyanidins: A comprehensive review. Biomed. Pharmacother. 2019, 116, 108999. [CrossRef] [PubMed]

38. Handeland, M.; Grude, N.; Torp, T.; Slimestad, R. Black chokeberry juice (Aronia melanocarpa) reduces incidences of urinary tract infection among nursing home residents in the long term-A pilot study. Nutr. Res. 2014, 34, 518-525. [CrossRef]

39. Sainova, I.; Pavlova, V.; Alexieva, B.; Vavrek, I.; Nikolova, E.; Valcheva-Kuzmanova, S.; Markova, T.; Krachanova, M.; Denev, P. Chemoprotective, antioxidant and immunomodulatory in vitro effects of Aronia melanocarpa total extract on laboratory-cultivated normal and malignant cells. J. Biosci. Biotechnol. 2012, 35-43.

40. Lachowicz, S.; Oszmiański, J.; Kolniak-Ostek, J. Influence of different pectinolytic enzymes on bioactive compound content, antioxidant potency, colour and turbidity of chokeberry juice. Eur. Food Res. Technol. 2018, 244, 1907-1920. [CrossRef]

41. Oszmiański, J.; Lachowicz, S. Effect of the production of dried fruits and juice from chokeberry (Aronia melanocarpa L.) on the content and antioxidative activity of bioactive compounds. Molecules 2016, 21, 1098.

42. White, B.L.; Howard, L.R.; Prior, R.L. Impact of different stages of juice processing on the anthocyanin, flavonol, and procyanidin contents of cranberries. J. Agric. Food Chem. 2011, 59, 4692-4698. [CrossRef] 
43. Wilkes, K.; Howard, L.R.; Brownmiller, C.; Prior, R.L. Changes in Chokeberry (Aronia melanocarpa L.) Polyphenols during juice processing and storage. J. Agric. Food Chem. 2014, 62, 4018-4025. [CrossRef] [PubMed]

44. Davarcı, A.; Kadiroğlu, P.; Diblan, S.; Selli, S.; Kelebek, H. Influence of processing steps on phenolic composition of clarified and unclarified pomegranate juices as characterized by LC-DAD-ESI-MS/MS. J. Food Process. Preserv. 2019, 43, e14018. [CrossRef]

45. Lee, S.G.; Vance, T.M.; Nam, T.; Kim, D.; Koo, S.I.; Chun, O.K. Evaluation of pH differential and HPLC methods expressed as cyanidin-3-glucoside equivalent for measuring the total anthocyanin contents of berries. J. Food Meas. Charact. 2016, 10, 562-568. [CrossRef]

46. Lee, J.; Rennaker, C.; Wrolstad, R.E. Correlation of two anthocyanin quantification methods: HPLC and spectrophotometric methods. Food Chem. 2008, 110, 782-786. [CrossRef]

47. Skapska, S.; Marszałek, K.; Woźniak, Ł.; Zawada, K.; Wawer, I. Aronia dietary drinks fortified with selected herbal extracts preserved by thermal pasteurization and high pressure carbon dioxide. LWT Food Sci. Technol. 2017, 85, 423-426. [CrossRef]

48. Talcott, S.T.; Brenes, C.H.; Pires, D.M.; Pozo-Insfran, D.D. Phytochemical stability and color retention of copigmented and processed muscadine grape juice. J. Agric. Food Chem. 2003, 51, 957-963. [CrossRef]

49. Nowicka, P.; Teleszko, M.; Wojdyło, A. Changes of peach juices during the shelf-life and their in vitro effect on glycolipid digestion and neurotransmitter metabolism. Int. J. Food Sci. Technol. 2019, 54, 1865-1873. [CrossRef]

50. Wojdyło, A.; Nowicka, P.; Teleszko, M. Degradation kinetics of anthocyanins in sour cherry cloudy juices at different storage temperature. Processes 2019, 7, 367. [CrossRef]

51. Trošt, K.; Golc-Wondra, A.; Prošek, M.; Milivojevič, L. Anthocyanin degradation of blueberry-aronia nectar in glass compared with carton during storage. J. Food Sci. 2008, 73, S405-S411. [CrossRef]

52. Šic Žlabur, J.; Dobričević, N.; Galić, A.; Pliestić, S.; Voća, S. The influence of natural sweetener (Stevia rebaudiana Bertoni) on bioactive compounds content in chokeberry juice. J. Food Process. Preserv. 2017, 42, e13406. [CrossRef]

53. Kopjar, M.; Bilić, B.; Piližota, V. Influence of different extracts addition on total phenols, anthocyanin content and antioxidant activity of blackberry juice during storage. Croat. J. Food Sci. Technol. 2011, 3, 9-15.

54. Bimpilas, A.; Panagopoulou, M.; Tsimogiannis, D.; Oreopoulou, V. Anthocyanin copigmentation and color of wine: The effect of naturally obtained hydroxycinnamic acids as cofactors. Food Chem. 2016, 197, 39-46. [CrossRef] [PubMed]

55. Navruz, A.; Türkyılmaz, M.; Özkan, M. Colour stabilities of sour cherry juice concentrates enhanced with gallic acid and various plant extracts during storage. Food Chem. 2016, 197, 150-160. [CrossRef] [PubMed]

56. Li, J.; Song, H.; Dong, N.; Zhao, G. Degradation kinetics of anthocyanins from purple sweet potato (Ipomoea batatas L.) as affected by ascorbic acid. Food Sci. Biotechnol. 2013, 23, 89-96. [CrossRef]

57. Farr, J.; Giusti, M. Investigating the interaction of ascorbic acid with anthocyanins and pyranoanthocyanins. Molecules 2018, 23, 744. [CrossRef]

58. Levy, R.; Okun, Z.; Shpigelman, A. The influence of chemical structure and the presence of ascorbic acid on anthocyanins stability and spectral properties in purified model systems. Foods 2019, 8, 207. [CrossRef]

59. Stebbins, N.B.; Howard, L.R.; Prior, R.L.; Brownmiller, C.; Liyanage, R.; Lay, J.O.; Xiaoyu, Y.; Qian, S.Y. Ascorbic acid-catalyzed degradation of cyanidin-3-O- $\beta$-glucoside: Proposed mechanism and identification of a novel hydroxylated product. J. Berry Res. 2016, 6, 175-187. [CrossRef]

60. Roidoung, S.; Dolan, K.D.; Siddiq, M. Gallic acid as a protective antioxidant against anthocyanin degradation and color loss in vitamin-C fortified cranberry juice. Food Chem. 2016, 210, 422-427. [CrossRef]

61. Gérard, V.; Ay, E.; Morlet-Savary, F.; Graff, B.; Galopin, C.; Ogren, T.; Mutilangi, W.; Lalevée, J. Thermal and photochemical stability of anthocyanins from black carrot, grape juice, and purple sweet potato in model beverages in the presence of ascorbic acid. J. Agric. Food Chem. 2019, 67, 5647-5660. [CrossRef]

62. Arslan, D. Effects of degradation preventive agents on storage stability of anthocyanins in sour cherry concentrate. Agron. Res. 2015, 13, 892-899.

(C) 2020 by the authors. Licensee MDPI, Basel, Switzerland. This article is an open access article distributed under the terms and conditions of the Creative Commons Attribution (CC BY) license (http://creativecommons.org/licenses/by/4.0/). 